\title{
Study on Synthesis and Biological Evaluation of 3-Aryl Substituted Xanthone Derivatives as Novel and Potent Tyrosinase Inhibitors
}

\author{
Lihong Yu, ${ }^{a, \#}$ Liandi Chen,,${ }^{a, b \#}$ Guolin Luo, ${ }^{a}$ Licai Liu, ${ }^{a}$ Wenqi Zhu, ${ }^{a}$ Pengke Yan, ${ }^{b}$ \\ Peiquan Zhang, ${ }^{a}$ Chao Zhang, ${ }^{*, a}$ and Wenhao $\mathrm{Wu}^{*, a}$ \\ ${ }^{a}$ Key Laboratory of Molecular Target \& Clinical Pharmacology, School of Pharmaceutical Sciences and the Fifth \\ Affiliated Hospital, Guangzhou Medical University; Guangzhou 511436, Guangdong, China: and ${ }^{b}$ The Third Affiliated \\ Hospital of Guangzhou Medical University; Guangzhou 510150, Guangdong, China. \\ Received July 11, 2019; accepted August 29, 2019; advance publication released online September 6, 2019
}

\begin{abstract}
Tyrosinase plays a key role in the melanin biosynthesis since it catalyzes the transformation of tyrosine into L-dopaquinone. A large number of studies have also shown that molecules to efficiently inhibit the activity of tyrosinase would be potentially used in treating many depigmentation-related disorders. In this study, we targeted a series of structure-based 3-aryl substituted xanthone derivatives in which diverse functional groups were respectively attached on 3-aromatic ring moiety as new tyrosinase inhibitors. The results demonstrated that all obtained compounds had potent tyrosinase inhibitory activities with $\mathrm{IC}_{50}$ values at micromolar range. Especially, compound $4 \mathrm{t}$ was found to be the most active tyrosinase inhibitor with the $\mathrm{IC}_{50}$ value of $11.3 \mu \mathrm{M}$, uncovering that the introduction of the proper hydroxyl group in the 3-aromatic ring was beneficial for enhancing the inhibitory potency against tyrosinase. Moreover, the inhibition mechanism and inhibition kinetics studies revealed that compound $4 \mathrm{t}$ presented such inhibitory effect by acting as the reversible and competitive-uncompetitive mixed-II type inhibitor. Further molecular docking simulation showed that 3 -aromatic ring of compound $4 t$ was inserted into the narrow regions of binuclear copper-binding site at the bottom of the enzyme binding pocket, while the xanthone skeleton was positioned at the surface of tyrosinase. Taken together, these data suggested that such type of molecules might be utilized for the development of new and promising candidate for the treatment of depigmentation-related disorders.
\end{abstract}

Key words xanthone derivative; tyrosinase inhibitor; synthesis; inhibition mechanism

\section{Introduction}

Tyrosinase (EC 1.14.18.1), also known as polyphenoloxidase (PPO), is a multifunctional enzyme and structurally belong to the type-3 copper-containing protein family. ${ }^{1)}$ The crystallographic structure of tyrosinase from three different species has revealed that the active center of the dicopper ions coordinated by six histidine residues and a lipophilic long-narrow gorge near to the active center composed the ligand-binding domain (LBD) of tyrosinase. ${ }^{2)}$ This enzyme is widely distributed in nature and mainly employed as the rate-limiting step for the melanin biosynthesis through catalyzing two distinct reactions: the hydroxylation of tyrosine to 3,4-dihydroxyphenylalanine (DOPA) (called cresolase/monophenolase activity) and the oxidation of DOPA into ortho-quinone (dopaquinone) (called catecholase/diphenolase activity). Recently, the crystal structures and active binding pocket of enzyme-substrates (tyrosine and DOPA) were also analyzed. ${ }^{3)}$ Furthermore, the produced dopaquinone is highly reactive and can further spontaneously polymerize to generate brown pigments of high molecular weight, namely melanin, ${ }^{4,5)}$ which are responsible for the color of mammalian skin and hair and also plays an important role in the protection of the skin against UV light induced damage. ${ }^{6-10)}$ Despite these good physiological functions demonstrated by this enzyme, the overproduction of melanin would cause not only serious dermatological problems such as melasma, freckles, senile lentigines, age spots, and sites of actinic damage in human beings. ${ }^{11)}$ but also the

\footnotetext{
\# These authors contributed equally to this work.
}

undesired enzymatic browning of fruits and vegetables. ${ }^{12}$ ) Moreover, excessive accumulation of melanin in the mammalian brain caused by abnormal tyrosinase activity is linked to the neurodegenerative diseases including Parkinson's disease. ${ }^{13)}$ Obviously, the unregulated action of tyrosinase has become an important factor in a number of human disease etiologies. Accordingly, tyrosinase inhibitors have been ardently explored as an avenue for therapies to these diseases and have become increasingly important in agriculture and food industry, as well as in medicinal and cosmetic products. To date, a huge number of naturally occurring and synthetic compounds acting as the tyrosinase inhibitors have already been reported, ${ }^{14-19)}$ but most of them are not potent enough to put into practical use due to their weak inhibitory activities or safety concerns. Undoubtedly, it is still necessary to develop new tyrosinase inhibitors with improved therapeutic profiles.

Xanthones are a class of oxygen-containing heterocycles with $\gamma$-pyran moiety condensed with two benzene rings, which are widely distributed in nature. ${ }^{18)}$ In recent years, xanthone derivatives have been received considerable attention in the field of medicinal chemistry because of their diversely biological functions, ${ }^{20,21)}$ such as anti-oxidant, ${ }^{22)}$ anti-hypertensive, ${ }^{23)}$ anti-convulsant, ${ }^{24)}$ anti-cholinesterase, ${ }^{25)}$ anti-malarial, ${ }^{26)}$ antimicrobial, ${ }^{27)}$ anti-inflammatory, ${ }^{28)}$ and anti-cancer activities. ${ }^{29}$ Besides, they also served as the effective inhibitors of several enzymes like $\alpha$-glycosidase, ${ }^{30,31)}$ topoisomerase, ${ }^{32)}$ proteinkinase, ${ }^{33)}$ aromatase. ${ }^{34)}$ Driven by both the biologically applied powers and the favorable pharmacological properties, indeed, xanthone skeleton has been defined as one of the privileged 
structural motifs for next stage of certain new drug screening and discovery.

On the other hand, polyphenol derivatives have attracted considerable attention compared with the other well-known tyrosinase inhibitors due to their favorable interaction with the hydrophobic protein pocket surrounding the binuclear copper active center of tyrosinase. ${ }^{35)}$ As a result, several different kinds of polyphenol compounds as the tyrosinase inhibitors have been reported, such as flavanones, ${ }^{36)}$ chalcones, ${ }^{37)}$ aurones, ${ }^{37)}$ resveratrols, ${ }^{38)}$ benzoate ester derivatives, ${ }^{39)}$ hydroxylated biphenyls, ${ }^{40)}$ hydroxyl substituted benzaldoximes. ${ }^{41)}$ and thiosemicarbazone derivatives. ${ }^{42-44)}$ On the contrary, despite most of naturally occurring or synthetic xanthones possess a polyphenol moiety, ${ }^{44)}$ their tyrosinase inhibitory activity have not yet been studied. On the basis of the crystallographic structure of tyrosinase and by analogy with the chemical structures of xanthones and other reported tyrosinase inhibitors, we reasoned that a proper introduction of the substituent to the xanthone core might deliver the acceptable inhibitory effect against tyrosinase through the potent interaction with the LBD of tyrosinase.

Take advantage of the above information and as a part of our ongoing studies on the synthetic and application of new biologically active compounds as the promising candidates for new drug discovery. Herein, a series of 3-aryl substituted xanthones bearing various functional groups (e.g. hydroxyl, methoxyl, formyl, carboxyl, methoxy carbonyl, acetyl and thiosemicarbazide) were designed, synthesized and evaluated as novel tyrosinase inhibitors. Moreover, the inhibition mechanism and inhibition kinetics of the selected compounds were investigated. Besides, the molecular docking analysis was also performed to elucidate the inhibition binding mode of the potent xanthones with the LBD of tyrosinase. We hope that the present findings can provide the scientific evidence to lead to the discovery of alternative and highly efficient pharmacological agents for the treatment of tyrosinase-related disorders.

\section{Results and Discussion}

Chemistry Taking account into the specificity of hydroxylated flavone structure as the tyrosinase inhibitor, we herein design 3-aryl substituted xanthone derivatives by introducing hydroxylated and other functionalities to screen and then to disclose and the key factors such as the efficient substituent and its position for determining the inhibitory ability against tyrosinase. The synthetic route of target compounds was shown in Chart 1. Briefly, the parent nucleus of xanthone $\mathbf{1}$ was firstly prepared via a condensation reaction of salicylic acid and phloroglucinol in the presence of Eaton's reagent at $80^{\circ} \mathrm{C}^{46)}$ It was then treated with triflic anhydride and trimethylamine in dichloromethane to give the triflated intermediate 2 in a decent yield of $87 \%$. Because of the existence of the hydrogen bond between hydroxyl group at position-1 and<smiles>CCOc1cc(O)cc2oc3cc(C)cc(O)c3c(=O)c12</smiles>

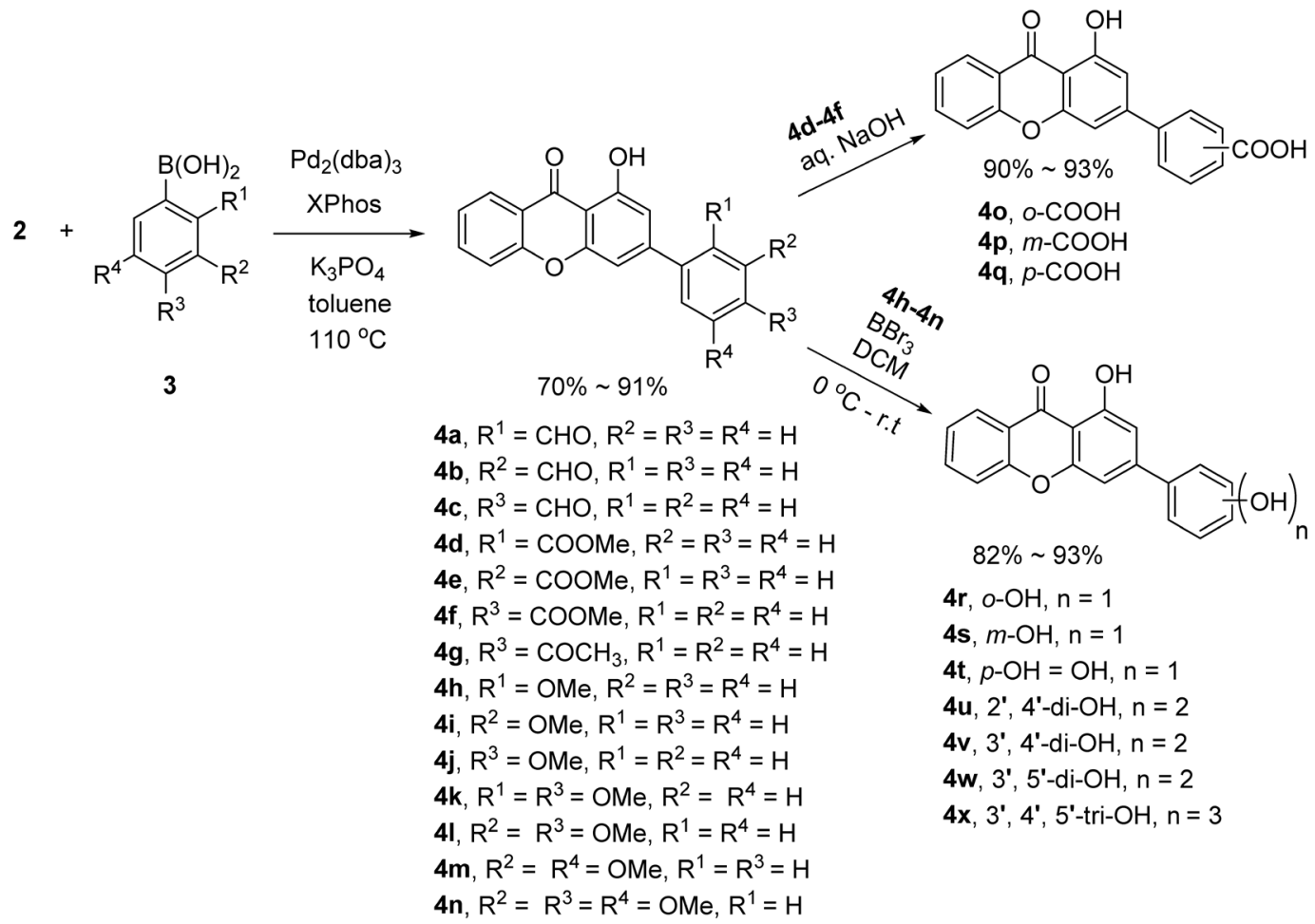

Chart 1. Synthesis of 3-Aryl Substituted Xanthone Derivatives 
carbonyl part at position-9, the triflate moiety was regioselectively attached at 3-hydroxyl position of xanthone 1. Subsequently, treatment of triflate $\mathbf{2}$ with appropriately substituted phenyl boronic acid 3 in the presence of $\mathrm{K}_{3} \mathrm{PO}_{4}$ proceeded smoothly via the classical Suzuki-Miyaura coupling to afford 3-aryl substituted xanthone derivatives $\mathbf{4 a - 4 n}$ in good yields, in which $\mathrm{Pd}_{2}(\mathrm{dba})_{3}$ and XPhos were employed as the ligand and catalyst, respectively. Moreover, carboxyl substituted compounds $\mathbf{4 o - 4 q}$ can be obtained from methoxycarbonyl xanthones $\mathbf{4 d}-\mathbf{4 f}$ by the convenient hydrolysis in $\mathrm{NaOH}$ solution. Finally, demethylation of methoxyl xanthones $\mathbf{4 h}-\mathbf{4 n}$ with boron tribromide in dichloromethane at $0^{\circ} \mathrm{C}$ was carried out to provide the corresponding 3-polyphenolsubstituted xanthone derivatives $\mathbf{4 r}-\mathbf{4 x}$ in excellent yields.

Biological Activity To explore the inhibitory effect of xanthone derivatives and define the importance of 3-aryl moiety, all the newly synthesized compounds $\mathbf{4 a}-\mathbf{4 x}$ were screened for the inhibitory activity on diphenolase of mushroom tyrosinase, where the well-known tyrosinase inhibitor kojic acid was used as the standard reference. The structures and $\mathrm{IC}_{50}$ values of all the synthesized compounds were summarized as shown in Table 1. The result showed that all the target compounds have favorable tyrosinase inhibitory activities compared with the parent compound with different inhibition profiles (the ranges of $\mathrm{IC}_{50}$ values from 11.3 to $115.8 \mu \mathrm{M}$ vs. 1-hydroxyl xanthone $\left.\mathrm{IC}_{50}>150 \mu \mathrm{M}\right)$, which was in agreement with our structure-based design. Among them, compounds $\mathbf{4 r}-\mathbf{4 t}$ bearing a hydroxyl group on the 3-aryl part demonstrated more potent tyrosinase inhibitory activities than that of these bearing other hydrogen-bond donor/receptor, such as formyl $(\mathbf{4 a}-\mathbf{4 c})$, ester (4d-4f) acetyl (4g), or carboxyl $(\mathbf{4 o}-\mathbf{4 q})$ groups. Especially, the compound $4 \mathbf{t}$ was found to be the most active tyrosinase inhibitor with the $\mathrm{IC}_{50}$ value of $11.3 \mu \mathrm{M}$, even more active than kojic acid $\left(\mathrm{IC}_{50}=17.3 \mu \mathrm{M}\right)$. Taken together, the results revealed that: (1) the introduction of the hydroxyl group on the 3-aryl part obviously facilitated tyrosinase inhibitory activity, and (2) the position of the hydroxyl group played a vital role in determining the tyrosinase inhibitory activity, and in the present investigation, the para-position was optimal. It should be emphasized that their corresponding 3-mono-methoxyphenyl substituted derivatives $\mathbf{4 h}-\mathbf{4 j}$ exhibited a less efficiency for the inhibition of tyrosinase. For example, compound $\mathbf{4 j}$ manifested a relatively low inhibitory activity with the $\mathrm{IC}_{50}$ value of $36.5 \mu \mathrm{M}$, which was 3 -fold less than that of $\mathbf{4 t}$. Moreover, further loss of the inhibitory activity against tyrosinase was detected from compounds

Table 1. Structures and Inhibitory Activities of All Synthesized Compounds<smiles>[R]c1cc(-c2cc([R])c3c(=O)c4ccccc4oc3c2)c([R])c([R])c1[R]</smiles>

\begin{tabular}{|c|c|c|c|c|c|}
\hline Compound & $\mathrm{R}^{1}$ & $\mathrm{R}^{2}$ & $\mathrm{R}^{3}$ & $\mathrm{R}^{4}$ & $\mathrm{IC}_{50}(\mu \mathrm{M})^{a)}$ \\
\hline $4 a$ & $\mathrm{CHO}$ & $\mathrm{H}$ & $\mathrm{H}$ & $\mathrm{H}$ & $45.6 \pm 0.25$ \\
\hline $4 b$ & $\mathrm{H}$ & $\mathrm{CHO}$ & $\mathrm{H}$ & $\mathrm{H}$ & $54.1 \pm 0.37$ \\
\hline $4 c$ & $\mathrm{H}$ & $\mathrm{H}$ & $\mathrm{CHO}$ & $\mathrm{H}$ & $42.1 \pm 0.23$ \\
\hline $4 d$ & COOMe & $\mathrm{H}$ & $\mathrm{H}$ & $\mathrm{H}$ & $78.1 \pm 0.34$ \\
\hline $4 e$ & $\mathrm{H}$ & COOMe & $\mathrm{H}$ & $\mathrm{H}$ & $115.8 \pm 0.38$ \\
\hline $4 f$ & $\mathrm{H}$ & $\mathrm{H}$ & COOMe & $\mathrm{H}$ & $56.1 \pm 0.31$ \\
\hline $4 g$ & $\mathrm{H}$ & $\mathrm{H}$ & $\mathrm{COCH}_{3}$ & $\mathrm{H}$ & $45.1 \pm 0.28$ \\
\hline $4 h$ & $\mathrm{OMe}$ & $\mathrm{H}$ & $\mathrm{H}$ & $\mathrm{H}$ & $82.2 \pm 0.30$ \\
\hline $4 i$ & $\mathrm{H}$ & $\mathrm{OMe}$ & $\mathrm{H}$ & $\mathrm{H}$ & $109.1 \pm 0.35$ \\
\hline $4 j$ & $\mathrm{H}$ & $\mathrm{H}$ & $\mathrm{OMe}$ & $\mathrm{H}$ & $36.5 \pm 0.18$ \\
\hline $4 k$ & $\mathrm{OMe}$ & $\mathrm{H}$ & $\mathrm{OMe}$ & $\mathrm{H}$ & $37.4 \pm 0.20$ \\
\hline 41 & $\mathrm{H}$ & $\mathrm{OMe}$ & $\mathrm{OMe}$ & $\mathrm{H}$ & $34.8 \pm 0.21$ \\
\hline $4 m$ & $\mathrm{H}$ & $\mathrm{OMe}$ & $\mathrm{H}$ & $\mathrm{OMe}$ & $39.8 \pm 0.23$ \\
\hline $4 n$ & $\mathrm{H}$ & $\mathrm{OMe}$ & $\mathrm{OMe}$ & $\mathrm{OMe}$ & $35.2 \pm 0.27$ \\
\hline 40 & $\mathrm{COOH}$ & $\mathrm{H}$ & $\mathrm{H}$ & $\mathrm{H}$ & $55.1 \pm 0.31$ \\
\hline $4 p$ & $\mathrm{H}$ & $\mathrm{COOH}$ & $\mathrm{H}$ & $\mathrm{H}$ & $73.9 \pm 0.38$ \\
\hline $4 q$ & $\mathrm{H}$ & $\mathrm{H}$ & $\mathrm{COOH}$ & $\mathrm{H}$ & $44.2 \pm 0.23$ \\
\hline $4 r$ & $\mathrm{OH}$ & $\mathrm{H}$ & $\mathrm{H}$ & $\mathrm{H}$ & $14.1 \pm 0.15$ \\
\hline $4 s$ & $\mathrm{H}$ & $\mathrm{OH}$ & $\mathrm{H}$ & $\mathrm{H}$ & $16.2 \pm 0.19$ \\
\hline $4 t$ & $\mathrm{H}$ & $\mathrm{H}$ & $\mathrm{OH}$ & $\mathrm{H}$ & $11.3 \pm 0.16$ \\
\hline $4 u$ & $\mathrm{OH}$ & $\mathrm{H}$ & $\mathrm{OH}$ & $\mathrm{H}$ & $53.6 \pm 0.29$ \\
\hline $4 v$ & $\mathrm{H}$ & $\mathrm{OH}$ & $\mathrm{OH}$ & $\mathrm{H}$ & $50.7 \pm 0.28$ \\
\hline $4 w$ & $\mathrm{H}$ & $\mathrm{OH}$ & $\mathrm{H}$ & $\mathrm{OH}$ & $92.6 \pm 0.38$ \\
\hline $4 x$ & $\mathrm{H}$ & $\mathrm{OH}$ & $\mathrm{OH}$ & $\mathrm{OH}$ & $52.6 \pm 0.26$ \\
\hline 1 & & & & & $>150$ \\
\hline Kojic acid & & & & & $17.3 \pm 0.15$ \\
\hline
\end{tabular}

a) All compounds were examined in a set of experiments repeated three times. $\mathrm{IC}_{50}$ values of compounds represent the concentration that caused $50 \%$ enzyme activity loss. 
4h and $4 \mathbf{i}$ since they gave the relatively high $\mathrm{IC}_{50}$ values (for 4h, $\mathrm{IC}_{50}=82.2 \mu \mathrm{M}$; for $\left.4 \mathbf{i}, \mathrm{IC}_{50}=109.1 \mu \mathrm{M}\right)$, compared with 4t. Similarly, it was found that either ortho- or meta-methoxyl substituted inhibitors were less active than para-substituted analogues, which further validated the importance of the substituent attached at the para-position. Meanwhile, the results also implied that the hydroxyl substituent might form the potential hydrogen-bond interaction with the LBD of tyrosinase to contribute the inhibition of tyrosinase.

Compared with compounds $\mathbf{4 r}-\mathbf{4 t}$, unfortunately, the results from Table 1 showed that dihydroxylated compounds $\mathbf{4 u - 4 w}$ possessed relatively weak tyrosinase inhibitory potency, revealing that the incorporation of an additional hydroxyl group onto the 3-aryl moiety led to a reduction in potency. Of note, $\mathrm{IC}_{50}$ values of $\mathbf{4} \mathbf{u}-\mathbf{4} \mathbf{w}$ were less than their corresponding methoxyl-substituted compounds $\mathbf{4 k}-\mathbf{4 m}$. The results suggested that the nature, type and number of the substituent played a key role in determining inhibitory effects, possibly due to that the different interaction modes of the compound with the LBD of tyrosinase depended by the structure and size of the ligand was involved in these cases.

Interestingly, trimethoxy substituted compound 4n only exhibited comparable inhibitory activities compared with dimethoxy substituted analogues $\mathbf{4 1}, \mathbf{4 m}$. A similar result can be observed from trihydroxy substituted compounds $\mathbf{4 x}$. The main reason might be that, the introduction of the additional functional group led to the big steric hindrance, which prevented the substrate to access the dicopper ions active center of tyrosinase via the lipophilic long-narrow gorge near to the active center, thereby showing a relatively low tyrosinase inhibitory activity.

Inhibition Mechanism Inspired by the above findings, next we were sought to explore the inhibition mechanism of the selected compound $\mathbf{4 t}$. As illustrated in Fig. 1, the inhibition mechanism on mushroom tyrosinase by compound $\mathbf{4 t}$ for the oxidation of L-DOPA was studied. The results showed that, the plots of the remaining tyrosinase activity versus the concentrations of tyrosinase in the presence of different concentrations of $\mathbf{4} \mathbf{t}$ gave a family of straight lines, which all passed through the origin point. Increasing the concentration of $\mathbf{4 t}$ resulted in a decrease in the slope of the line, revealing that the inhibition of compound $\mathbf{4 t}$ on tyrosinase was reversible.

To further insight into the inhibition mechanism, we were interested to investigate the inhibitory type of compound $\mathbf{4 t}$ determined by Lineweaver-Burk double reciprocal plots. In the presence of $\mathbf{4 t}$, the kinetics of the enzyme was shown in Fig. 2. The results displayed that the plots of $1 / V$ versus $1 /[\mathrm{S}]$ gave four straight lines with different slopes that intersected one another in the third quadrant; with the increase of the concentration of $\mathbf{4 t}$, the values of $V_{\mathrm{m}}$ and $K_{\mathrm{m}}$ all descended, suggesting that $\mathbf{4 t}$ was a competitive-uncompetitive mixed-II type inhibitor.

Molecular Docking In order to further substantiate the interaction of the most active compound $\mathbf{4 t}$ with tyrosinase, the molecular docking simulation was implemented using SYBYL X-2.1 software. The crystal structure of Agaricus bisporus tyrosinase (PDB code: 2Y9X) was used for this study. ${ }^{47)}$ As shown in Fig. 3A, it displayed that tyrosinase had a very special binding pocket, which contained both spacious and narrow regions for the binding of its active ligands. The two copper ions located at the bottom of binding pocket were

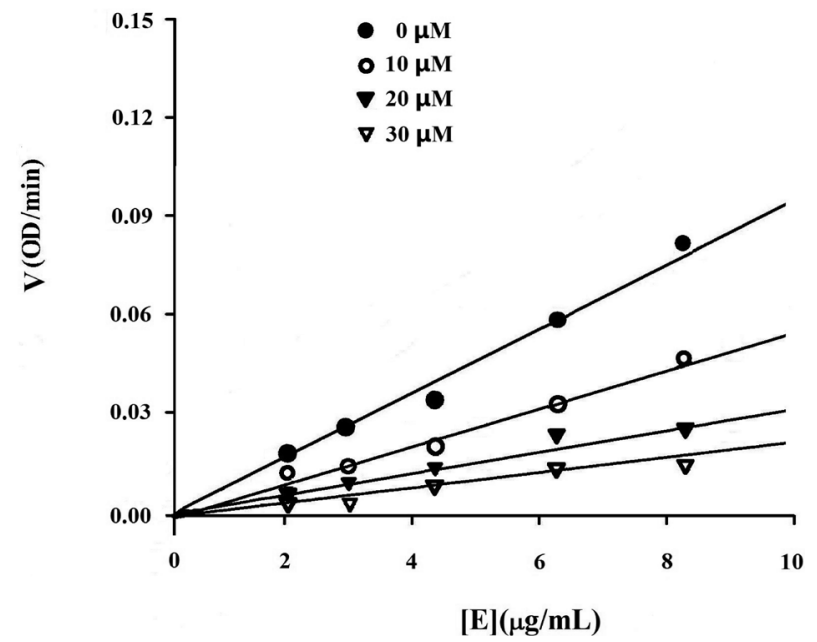

Fig. 1. Determination of the Inhibitory Effect of the Selected Compound $\mathbf{4 t}$ on Mushroom Tyrosinase for the Catalysis of L-DOPA

The concentrations of $\mathbf{4 t}$ for curves were $0,10,20$, and $30 \mu \mathrm{M}$, respectively.

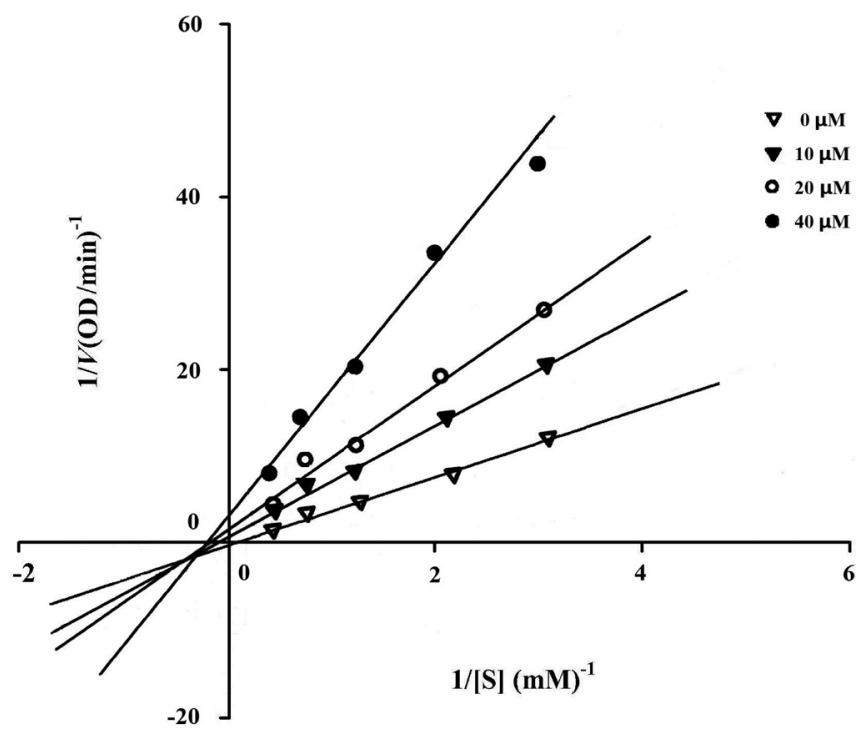

Fig. 2. Determination of the Inhibitory Type of the Selected Compound $4 \mathbf{t}$ on Mushroom Tyrosinase for the Catalysis of L-DOPA

The concentrations of $\mathbf{4 t}$ for curves were $0,10,20$, and $40 \mu \mathrm{M}$, respectively.

coordinated to the six histidine residues from the enzyme. ${ }^{48)}$ According to the crystal structure of tyrosinase, the inhibitor tropolone was small enough to be bound deeply in the binuclear copper-binding site and its oxygen atom had a short distance of approximately $3.5 \AA$ to either copper ion. Interestingly, the relatively large inhibitor $\mathbf{4 t}$ had a different binding mode. As the docking results demonstrated in Fig. 3A and B, compound $\mathbf{4 t}$ could be divided into two parts: the large part of xanthone skeleton and the small part of para-hydroxyphenyl group at position-3. As a result, the small part of the parahydroxyphenyl group could enter narrow regions of ligandbound pocket adopted a similar behavior as tropolone. In the binuclear copper-binding site, the distance between oxygen atom of para-hydroxyphenyl group and copper ion was $4.1 \AA$, which meant that the para-hydroxyphenyl group was not bound as deeply as tropolone ( $4.1 \AA$ vs. $3.5 \AA)$. Moreover, a same direction of the para-hydroxyphenyl group in active site 

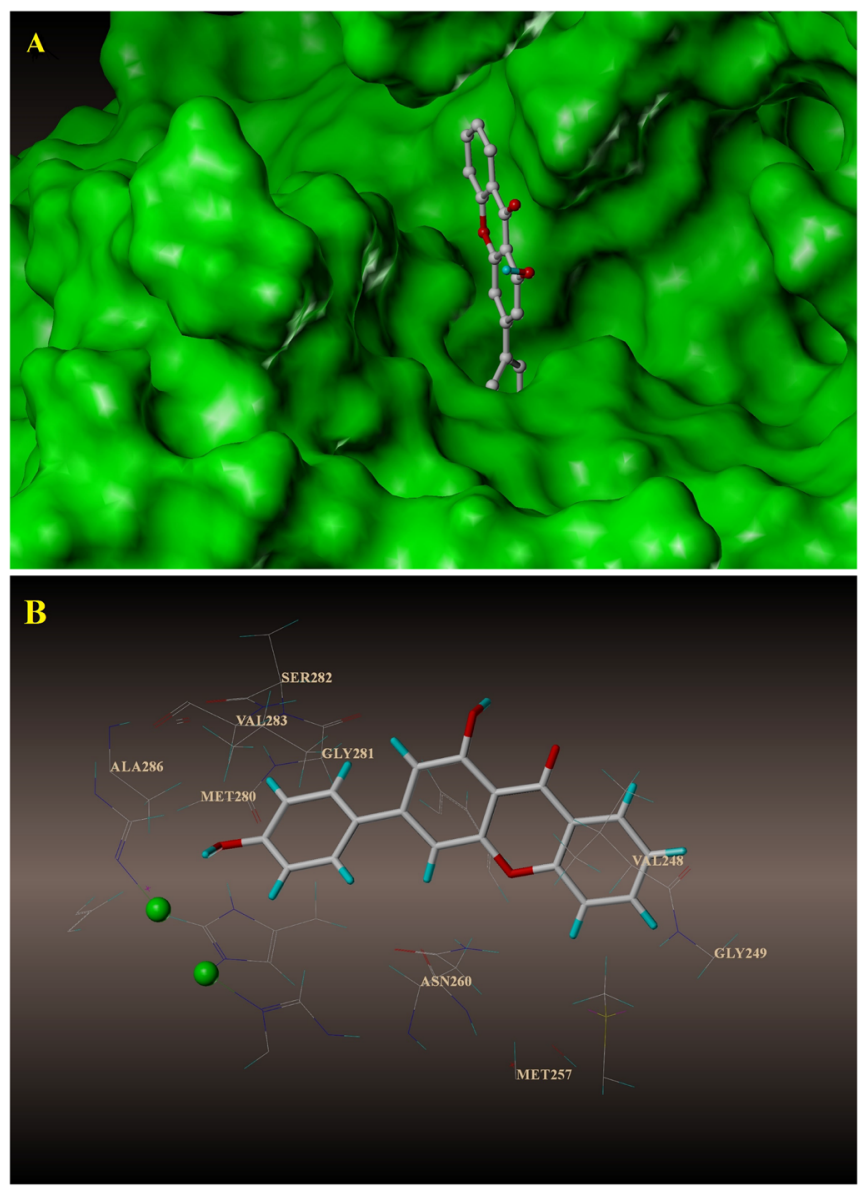

Fig. 3. (A) Surface and Binding Pocket with Compound 4t on Tyrosinase; (B) Predicated Binding Mode of Compound 4t Docked with Tyrosinase at the Active Site

Copper ions are displayed as green sphere. (Color figure can be accessed in the online version.)

was observed compared with tropolone and it was manifested that the benzene ring part was almost parallel with tropolone which ever existed in the binding pocket. Nevertheless, the benzene ring of the para-hydroxyphenyl group fitted into the hydrophobic residues of binding pocket formed by Met280, Gly281, Ser282, Val283, and Ala286. On the other hand, the large part of xanthone skeleton was mostly positioned at the surface of the enzyme binding pocket with hydrophobic residues surrounded by Val248, Gly249, and Met257. In addition, the dihedral angle between the xanthone scaffold and the para-hydroxyphenyl moiety was nearly 120 degree, which made the xanthone skeleton block the substrate such as LDOPA to access the binuclear copper-binding active site at the bottom of the enzyme binding pocket. Taken together, the inhibitor $\mathbf{4 t}$ presented a potent inhibition against tyrosinase by acting as a reversible and competitive-uncompetitive mixed-II type inhibitor, which was consistent with the results from the inhibitory activity evaluation and the inhibition mechanism and inhibition kinetics studies. Finally, it should be noted that two or three hydroxy xanthones such as compounds $\mathbf{4 v}$ and $\mathbf{4 x}$ have a different binding mode compare with compound $\mathbf{4 t}$ according to their docking results. The part that insert into narrow regions of ligand-bound pocket is xanthone scaffold rather than 3-aryl moiety and xanthone scaffold does not entre as deeply as 3 -aryl of compound $\mathbf{4 t}$, it is proven by a relatively low total score. One possible reason could attribute to steric hinder and this result can explain the inhibitory activity of compound $\mathbf{4 t}$ is more potent.

\section{Conclusion}

In summary, we have defined for the first time a series of 3 -aryl substituted xanthone derivatives with the corresponding diversely functional groups as novel and potent tyrosinase inhibitors. The results demonstrated that all synthesized compounds had potent tyrosinase inhibitory activities. Especially, the compound $\mathbf{4 t}$ exhibited the most potent tyrosinase inhibitory activity with the $\mathrm{IC}_{50}$ value of $11.3 \mu \mathrm{M}$, which was more active than the well-known tyrosinase inhibitor kojic acid. The structure-activity relationships (SARs) analysis indicated that: (1) the introduction of the hydroxyl group on the 3-aryl part obviously facilitated tyrosinase inhibitory activity, (2) the position and number of the hydroxyl group played a vital role in determining the tyrosinase inhibitory activity. Moreover, the inhibition mechanism and inhibition kinetics studies revealed that compound $\mathbf{4 t}$ exhibited such inhibitory effect by acting as the reversible and competitive-uncompetitive mixed-II type tyrosinase inhibitor. The subsequent molecular docking simulation further disclosed the feasible interaction mode between 4t with the LBD of tyrosinase. Taken together, these results suggested that such type of 3-aryl xanthone compounds could serve as a new class of promising candidates for future investigation to treat the tyrosinase-related disorders.

\section{Experimental}

Chemistry The ${ }^{1} \mathrm{H}-\mathrm{NMR}$ and ${ }^{13} \mathrm{C}-\mathrm{NMR}$ spectra were recorded using tetramethylsilane (TMS) as the internal standard on a Bruker Avnace III 400 spectrometer or JOEL ECA-400 spectrometers at $400 \mathrm{MHz}$ and $101 \mathrm{MHz}$ in either $\mathrm{CDCl}_{3}$, DMSO- $d_{6}$ or Acetone- $d_{6}$. Chemical shifts $(\delta)$ were referenced to TMS as an internal standard $\left({ }^{1} \mathrm{H}-\mathrm{NMR},{ }^{13} \mathrm{C}-\mathrm{NMR}\right)$. Coupling constants are given in $\mathrm{Hz}$. High-resolution (HR) MS were obtained with Shimazu LCMS-IT-TOF mass spectrometer or Thermo-DFS mass spectrometer. Reaction progress was monitored using analytical TLC on precoated silica gel GF254 (Qingdao Haiyang Chemical Plant, Qingdao, China) plates and the spots were detected under UV light $(254 \mathrm{~nm})$. Flash column chromatography was performed with silica gel (200-300 mesh) purchased from Qingdao Haiyang Chemical Co., Ltd. All commercially available compounds and solvents were used without further purification. Mushroom tyrosinase (activity of the enzyme is $\geq 1000 \mathrm{unit} / \mathrm{mg}$ ) was purchased from Merck Life Science (Shanghai) Co., Ltd. All the purity of tested compounds was determined by combining ${ }^{1} \mathrm{H}-\mathrm{NMR}$ and HR-MS to ensure the purity over $95 \%$. Some selected compounds such $\mathbf{4 t}$, its purity was further examined by HPLC.

1-Hydroxy-9-oxo-9H-xanthen-3-yl Trifluoromethanesulfonate 2 Under nitrogen, xanthone $1(0.69 \mathrm{~g}, 3 \mathrm{mmol})$ was dissolved in $60 \mathrm{~mL}$ of dry $\mathrm{CH}_{2} \mathrm{Cl}_{2}$ in a $250 \mathrm{~mL}$ Schlenk flask. Analytical-grade $\mathrm{Et}_{3} \mathrm{~N}(15 \mathrm{~mL})$ was added and the solution was cooled to $0^{\circ} \mathrm{C}$. Then triflic anhydride $(1.1 \mathrm{~mL}, 6.6 \mathrm{mmol})$ was added dropwise via syringe over $5 \mathrm{~min}$ and the mixture was stirred at $0^{\circ} \mathrm{C}$ for $30 \mathrm{~min}$. The reaction solution was following allowed to warm up to $50^{\circ} \mathrm{C}$ and kept stirred for another $6 \mathrm{~h}$. At the conclusion of the reaction, the mixture was quenched with saturated $\mathrm{NaCl}$ solution and extracted by $\mathrm{CH}_{2} \mathrm{Cl}_{2}$ three times. The combined extract was then washed successively 
with aqueous $\mathrm{HCl}(10 \%)$, saturated $\mathrm{NaHCO}_{3}$ and brine. The organic layer was dried over $\mathrm{Na}_{2} \mathrm{SO}_{4}$ and concentrated under reduced pressure. The residue was purified by silica gel column chromatography gave the desired intermediate $\mathbf{2}$ as a yellow solid, yield $87 \%$. ${ }^{1} \mathrm{H}-\mathrm{NMR}(400 \mathrm{MHz}$, dimethyl sulfoxide (DMSO)- $\left.d_{6}\right) \delta$ : $12.90(\mathrm{~s}, 1 \mathrm{H}), 8.22-8.19$ (dd, $J=8.0$, $1.5 \mathrm{~Hz}, 1 \mathrm{H}), 7.99-7.95$ (ddd, $J=8.7,7.2,1.7 \mathrm{~Hz}, 1 \mathrm{H}), 7.71-7.69$ $(\mathrm{d}, J=8.5,1 \mathrm{H}), 7.58-7.54(\mathrm{ddd}, J=8.1,7.2,1.0 \mathrm{~Hz}, 1 \mathrm{H})$, $7.38(\mathrm{~d}, J=2.3 \mathrm{~Hz}, 1 \mathrm{H}), 7.05(\mathrm{~d}, J=2.3 \mathrm{~Hz}, 1 \mathrm{H}) .{ }^{13} \mathrm{C}-\mathrm{NMR}$ $\left(101 \mathrm{MHz}, \mathrm{DMSO}-d_{6}\right) \delta: 181.67,162.97,156.92,156.10,154.11$, $137.40,126.02,125.72,120.43,120.24\left(J_{\mathrm{C}-\mathrm{F}}=160 \mathrm{~Hz}, 1 \mathrm{C}\right)$, $118.54\left(J_{\mathrm{C}-\mathrm{F}}=160 \mathrm{~Hz}, 1 \mathrm{C}\right), 117.05\left(J_{\mathrm{C}-\mathrm{F}}=160 \mathrm{~Hz}, 1 \mathrm{C}\right), 108.92$, 104.43, 101.84. Electrospray ionization (ESI)-HR-MS Calcd for $\mathrm{C}_{14} \mathrm{H}_{7} \mathrm{O}_{6} \mathrm{~F}_{3} \mathrm{~S}[\mathrm{M}+\mathrm{H}]^{+}$: 360.9949 . Found: 360.9982 .

General Procedure for the Preparation of 4a-4n An oven dried round bottom flask was charged with compound 2 ( $1 \mathrm{mmol}, 1.0$ equiv), $\operatorname{Pd}_{2}(\mathrm{dba})_{3}(5 \mathrm{~mol} \%)$, XPhos $(6 \mathrm{~mol} \%)$, $\mathrm{K}_{3} \mathrm{PO}_{4}$ ( $3 \mathrm{mmol}, 3.0$ equiv) and phenylboronic acid 3 ( $2 \mathrm{mmol}$, 2.0 equiv.). The flask was capped with a rubber septum and twice evacuated and backfilled with $\mathrm{N}_{2}$. Toluene $(30 \mathrm{~mL})$ was injected sequentially and the reaction was stirred at $110^{\circ} \mathrm{C}$ for $24 \mathrm{~h}$. After completion, the reaction mixture was passed through small pad of celite. The filtrate was diluted with EtOAc and water, the combined organic layer was dried over $\mathrm{Na}_{2} \mathrm{SO}_{4}$ and concentrated in vacuum. The obtained crude product was purified by flash chromatography on silica gel gave the corresponding target compounds $\mathbf{4 a - 4 n}$.

2-(1-Hydroxy-9-oxo-9H-xanthen-3-yl)benzaldehyde (4a)

Compound 2 was treated with (2-formylphenyl)boronic acid (3a) according to general procedure to give the desired product $4 \mathbf{a}$ as yellow solid. Yield 73\%, ${ }^{1} \mathrm{H}-\mathrm{NMR}(400 \mathrm{MHz}$, DMSO- $\left.d_{6}\right) \delta: 12.67(\mathrm{~s}, 1 \mathrm{H}), 9.99(\mathrm{~s}, 1 \mathrm{H}), 8.25-8.22$ (dd, $J=8.0,1.6 \mathrm{~Hz}, 1 \mathrm{H}), 7.99-7.94(\mathrm{~m}, 2 \mathrm{H}), 7.83-7.79(\mathrm{td}, J=7.5$, $1.4 \mathrm{~Hz}, 1 \mathrm{H}), 7.71-7.66(\mathrm{~m}, 2 \mathrm{H}), 7.62(\mathrm{~d}, J=7.7 \mathrm{~Hz}, 1 \mathrm{H}), 7.56$ $(\mathrm{t}, J=7.6 \mathrm{~Hz}, 1 \mathrm{H}), 7.20(\mathrm{~d}, J=1.4 \mathrm{~Hz}, 1 \mathrm{H}), 6.93(\mathrm{~d}, J=1.4 \mathrm{~Hz}$, 1H). ${ }^{13} \mathrm{C}-\mathrm{NMR}\left(101 \mathrm{MHz}, \mathrm{DMSO}-d_{6}\right) \delta: 191.95,182.04,161.07$, $156.25,155.88,147.35,143.45,137.15,134.45,133.75,131.03$, $129.55,128.43,125.98,125.33,120.52,118.60,112.35,109.54$, 108.17. ESI-HR-MS Calcd for $\mathrm{C}_{20} \mathrm{H}_{12} \mathrm{O}_{4}[\mathrm{M}+\mathrm{H}]^{+}: 317.0769$. Found: 317.0803.

3-(1-Hydroxy-9-oxo-9H-xanthen-3-yl)benzaldehyde (4b)

Compound 2 was treated with (3-formylphenyl)boronic acid (3b) according to general procedure to give the desired product $4 \mathbf{b}$ as yellow solid. Yield $70 \%,{ }^{1} \mathrm{H}-\mathrm{NMR}(400 \mathrm{MHz}$, $\left.\mathrm{CDCl}_{3}\right) \delta: 12.73(\mathrm{~s}, 1 \mathrm{H}), 10.14(\mathrm{~s}, 1 \mathrm{H}), 8.33(\mathrm{~d}, J=7.9 \mathrm{~Hz}$, $1 \mathrm{H}), 8.21(\mathrm{~s}, 1 \mathrm{H}), 7.98(\mathrm{t}, J=7.9 \mathrm{~Hz}, 2 \mathrm{H}), 7.81(\mathrm{t}, J=7.8 \mathrm{~Hz}$, $1 \mathrm{H}), 7.70(\mathrm{t}, J=7.7 \mathrm{~Hz}, 1 \mathrm{H}), 7.54(\mathrm{~d}, J=8.3 \mathrm{~Hz}, 1 \mathrm{H}), 7.46(\mathrm{t}$, $J=7.5 \mathrm{~Hz}, 1 \mathrm{H}), 7.25(\mathrm{~d}, J=1.4 \mathrm{~Hz}, 1 \mathrm{H}), 7.11(\mathrm{~d}, J=1.3 \mathrm{~Hz}$, 1H). ${ }^{13} \mathrm{C}-\mathrm{NMR} \quad\left(126 \mathrm{MHz}, \mathrm{DMSO}-d_{6}\right) \quad \delta: 193.54, \quad 181.88$, $161.84,156.73,156.32,148.02,139.36,137.07,133.63,130.52$, $129.84,129.54,127.92,125.98,125.26,120.58,118.56,114.36$, 108.95, 106.05. ESI-HR-MS Calcd for $\mathrm{C}_{20} \mathrm{H}_{12} \mathrm{O}_{4}[\mathrm{M}+\mathrm{H}]^{+}$: 317.0769. Found: 317.0804.

4-(1-Hydroxy-9-oxo-9H-xanthen-3-yl)benzaldehyde (4c)

Compound 2 was treated with (4-formylphenyl)boronic acid (3c) according to general procedure to give the desired product $4 \mathrm{c}$ as yellow solid. Yield $70 \%,{ }^{1} \mathrm{H}-\mathrm{NMR}(400 \mathrm{MHz}$, DMSO- $\left.d_{6}\right) \delta$ : $12.60(\mathrm{~s}, 1 \mathrm{H}), 10.09(\mathrm{~s}, 1 \mathrm{H}), 8.21(\mathrm{~d}, J=7.9 \mathrm{~Hz}$, $1 \mathrm{H}), 8.08(\mathrm{~d}, J=8.1 \mathrm{~Hz}, 2 \mathrm{H}), 8.03(\mathrm{~d}, J=8.3 \mathrm{~Hz}, 2 \mathrm{H}), 7.95$ (t, $J=7.8 \mathrm{~Hz}, 1 \mathrm{H}), 7.69(\mathrm{~d}, J=8.5 \mathrm{~Hz}, 1 \mathrm{H}), 7.54(\mathrm{t}, J=7.6 \mathrm{~Hz}$, 1H), $7.51(\mathrm{~s}, 1 \mathrm{H}), 7.24(\mathrm{~s}, 1 \mathrm{H}) .{ }^{13} \mathrm{C}-\mathrm{NMR}\left(101 \mathrm{MHz}, \mathrm{DMSO}-d_{6}\right)$ $\delta: 193.27,181.85,161.72,156.57,156.27,147.81,143.98,137.06$, $136.72,130.55,128.59,125.94,125.24,120.53,118.53,109.21$, 108.38, 106.37. ESI-HR-MS Calcd for $\mathrm{C}_{20} \mathrm{H}_{12} \mathrm{O}_{4}[\mathrm{M}+\mathrm{H}]^{+}$: 317.0769. Found: 317.0805.

Methyl 2-(1-Hydroxy-9-oxo-9H-xanthen-3-yl)benzoate (4d)

Compound 2 was treated with (2-(methoxycarbonyl)phenyl)boronic acid (3d) according to general procedure to give the desired product $\mathbf{4 d}$ as yellow solid. Yield $73 \%,{ }^{1} \mathrm{H}-\mathrm{NMR}$ $\left(400 \mathrm{MHz}, \mathrm{DMSO}-d_{6}\right) \delta: 12.66(\mathrm{~s}, 1 \mathrm{H}), 8.30-8.28(\mathrm{dd}, J=8.0$, $1.7 \mathrm{~Hz}, 1 \mathrm{H}), 7.91-7.88$ (dd, $J=7.8,1.2 \mathrm{~Hz}, 1 \mathrm{H}), 7.77-7.73$ (ddd, $J=8.7,7.1,1.7 \mathrm{~Hz}, 1 \mathrm{H}), 7.59-7.55(\mathrm{td}, J=7.5,1.5 \mathrm{~Hz}, 1 \mathrm{H})$, $7.50-7.46(\mathrm{td}, J=7.5,1.3 \mathrm{~Hz}, 2 \mathrm{H}), 7.42-7.38(\mathrm{ddd}, J=8.2,7.2$, $1.1 \mathrm{~Hz}, 2 \mathrm{H}), 6.89$ (d, $J=1.5 \mathrm{~Hz}, 1 \mathrm{H}), 6.75(\mathrm{~d}, J=1.5 \mathrm{~Hz}, 1 \mathrm{H})$, $3.70(\mathrm{~s}, 3 \mathrm{H}) .{ }^{13} \mathrm{C}-\mathrm{NMR}\left(101 \mathrm{MHz}, \mathrm{CDCl}_{3}\right) \delta$ : 182.21, 168.26, $161.48,156.42,155.89,150.85,141.27,135.67,131.71,130.47$, $130.34,130.27,128.39,126.11,124.24,120.83,118.00,110.92$, 107.98, 107.31, 52.35. EI-HR-MS Calcd for $\mathrm{C}_{21} \mathrm{H}_{14} \mathrm{O}_{5}[\mathrm{M}+\mathrm{H}]^{+}$: 347.0875. Found: 347.0906 .

Methyl 3-(1-Hydroxy-9-oxo-9H-xanthen-3-yl)benzoate (4e)

Compound 2 was treated with (3-(methoxycarbonyl)phenyl)boronic acid (3e) according to general procedure to give the desired product $4 \mathrm{e}$ as yellow solid. Yield $71 \%,{ }^{1} \mathrm{H}-\mathrm{NMR}$ $\left(400 \mathrm{MHz}, \mathrm{CDCl}_{3}\right) \delta: 12.65(\mathrm{~s}, 1 \mathrm{H}), 8.34(\mathrm{t}, J=1.6 \mathrm{~Hz}, 1 \mathrm{H})$, $8.29-8.26(\mathrm{dd}, J=8.0,1.7 \mathrm{~Hz}, 1 \mathrm{H}), 8.11-8.08(\mathrm{dt}, J=7.8$, $1.4 \mathrm{~Hz}, 1 \mathrm{H}), 7.85-7.83$ (ddd, $J=7.8,2.0,1.2 \mathrm{~Hz}, 1 \mathrm{H}), 7.78-7.73$ (ddd, $J=8.7,7.1,1.7 \mathrm{~Hz}, 1 \mathrm{H}), 7.57-7.53(\mathrm{td}, J=7.8,0.5 \mathrm{~Hz}$, $1 \mathrm{H}), 7.49-7.47$ (dd, $J=8.5,1.1 \mathrm{~Hz}, 1 \mathrm{H}), 7.40-7.38$ (ddd, $J=8.1$, $7.1,1.0 \mathrm{~Hz}, 1 \mathrm{H}), 7.19(\mathrm{~d}, J=1.6 \mathrm{~Hz}, 1 \mathrm{H}), 7.06(\mathrm{~d}, J=1.6 \mathrm{~Hz}$, $1 \mathrm{H}), 3.96(\mathrm{~s}, 3 \mathrm{H}) .{ }^{13} \mathrm{C}-\mathrm{NMR}\left(101 \mathrm{MHz}, \mathrm{DMSO}-d_{6}\right) \delta: 182.03$, $166.76,162.22,156.65,156.43,148.72,139.69,135.74,131.71$, $131.09,130.05,129.26,128.59,126.12,124.32,120.84,117.99$, 109.25, 108.21, 105.74, 52.43. Electron ionization (EI)-HR-MS Calcd for $\mathrm{C}_{21} \mathrm{H}_{14} \mathrm{O}_{5}[\mathrm{M}+\mathrm{H}]^{+}$: 347.0875. Found: 347.0907 .

Methyl 4-(1-Hydroxy-9-oxo-9H-xanthen-3-yl)benzoate (4f)

Compound 2 was treated with (4-(methoxycarbonyl)phenyl)boronic acid (3f) according to general procedure to give the desired product $4 \mathrm{f}$ as yellow solid. Yield $76 \%,{ }^{1} \mathrm{H}-\mathrm{NMR}$ $\left(400 \mathrm{MHz}, \mathrm{DMSO}-d_{6}\right) \delta: 12.61(\mathrm{~s}, 1 \mathrm{H}), 8.22$ (dd, $J=8.0$, $1.6 \mathrm{~Hz}, 1 \mathrm{H}), 8.08(\mathrm{~d}, J=8.5 \mathrm{~Hz}, 2 \mathrm{H}), 8.02(\mathrm{~d}, J=8.5 \mathrm{~Hz}, 2 \mathrm{H})$, $7.96(\mathrm{td}, J=7.8,1.7 \mathrm{~Hz}, 1 \mathrm{H}), 7.70(\mathrm{~d}, J=8.3 \mathrm{~Hz}, 1 \mathrm{H}), 7.55(\mathrm{t}$, $J=7.6 \mathrm{~Hz}, 1 \mathrm{H}), 7.51(\mathrm{~d}, J=1.5 \mathrm{~Hz}, 1 \mathrm{H}), 7.24(\mathrm{~d}, J=1.5 \mathrm{~Hz}$, $1 \mathrm{H}), 3.90$ (s, 3H). ${ }^{13} \mathrm{C}-\mathrm{NMR}\left(101 \mathrm{MHz}, \mathrm{CDCl}_{3}\right) \quad \delta:$ 181.93, $166.63,162.14,156.51,156.35,148.49,143.64,135.66,130.46$, $130.25,127.34,126.05,124.25,120.77,117.88,109.31,108.30$, 105.80, 52.24. ESI-HR-MS Calcd for $\mathrm{C}_{21} \mathrm{H}_{14} \mathrm{O}_{5}[\mathrm{M}+\mathrm{H}]^{+}$: 347.0875. Found: 347.0904.

1-Hydroxy-3-(4-acetylphenyl)-9H-xanthen-9-one (4g)

Compound 2 was treated with (4-acetylphenyl)boronic acid (3g) according to general procedure to give the desired product $\mathbf{4 g}$ as yellow solid. Yield $76 \%,{ }^{1} \mathrm{H}-\mathrm{NMR}(400 \mathrm{MHz}$, DMSO) $\delta$ : $12.67(\mathrm{~s}, 1 \mathrm{H}), 8.30-8.27(\mathrm{dd}, J=7.9,1.7 \mathrm{~Hz}, 1 \mathrm{H})$, 8.08-8.04 (m, 2H), 7.80-7.72 (m, 3H), 7.50-7.48 (dd, $J=8.4$, $1.0 \mathrm{~Hz}, 1 \mathrm{H}), 7.43-7.49$ (ddd, $J=8.1,7.1,1.0 \mathrm{~Hz}, 1 \mathrm{H}), 7.18$ (d, $J=1.7 \mathrm{~Hz}, 1 \mathrm{H}), 7.05(\mathrm{~d}, J=1.6 \mathrm{~Hz}, 1 \mathrm{H}), 2.65(\mathrm{~s}, 3 \mathrm{H})$. ${ }^{13} \mathrm{C}-\mathrm{NMR}$ (101 MHz, DMSO) $\delta$ : 197.67, 182.06, 162.22, 156.61, $156.43,148.44,143.85,137.21,135.83,129.13,127.68,126.15$, $124.40,120.83,118.00,109.40,108.43,105.94,26.84$. EI-HRMS Calcd for $\mathrm{C}_{21} \mathrm{H}_{14} \mathrm{O}_{4}[\mathrm{M}+\mathrm{H}]^{+}:$331.0926. Found: 331.0970 .

1-Hydroxy-3-(2-methoxyphenyl)-9H-xanthen-9-one (4h)

Compound 2 was treated with (2-methoxyphenyl)boronic acid (3h) according to general procedure to give the desired 
product $4 \mathbf{h}$ as yellow solid. Yield $88 \%,{ }^{1} \mathrm{H}-\mathrm{NMR}(400 \mathrm{MHz}$, DMSO- $\left.d_{6}\right) \delta: 12.52(\mathrm{~s}, 1 \mathrm{H}), 8.21-8.19(\mathrm{dd}, J=8.0,1.6 \mathrm{~Hz}, 1 \mathrm{H})$, $7.95-7.90$ (ddd, $J=8.7,7.2,1.7 \mathrm{~Hz}, 1 \mathrm{H}), 7.67$ (d, $J=8.0 \mathrm{~Hz}$, $1 \mathrm{H}), 7.54-7.50(\mathrm{td}, J=7.5,1.0 \mathrm{~Hz}, 1 \mathrm{H}), 7.47-7.42(\mathrm{~m}, 2 \mathrm{H})$, $7.20-7.17(\mathrm{dd}, J=8.8,1.1 \mathrm{~Hz}, 2 \mathrm{H}), 7.10-7.16 \quad(\mathrm{td}, J=7.5$, $1.0 \mathrm{~Hz}, 1 \mathrm{H}), 6.95(\mathrm{~d}, J=1.4 \mathrm{~Hz}, 1 \mathrm{H}), 3.83(\mathrm{~s}, 3 \mathrm{H}) .{ }^{13} \mathrm{C}-\mathrm{NMR}$ $\left(101 \mathrm{MHz}, \mathrm{DMSO}-d_{6}\right) \delta: 181.76,160.78,156.68,156.24,155.78$, $147.89,136.86,130.92,130.88,128.24,125.90,125.06,121.41$, $120.48,118.52,112.50,111.60,108.46,107.52,56.10$. ESI-HRMS Calcd for $\mathrm{C}_{20} \mathrm{H}_{14} \mathrm{O}_{4}[\mathrm{M}+\mathrm{H}]^{+}:$319.0926. Found: 319.0963 .

1-Hydroxy-3-(3-methoxyphenyl)-9H-xanthen-9-one (4i)

Compound 2 was treated with (3-methoxyphenyl)boronic acid (3i) according to general procedure to give the desired product $4 \mathbf{i}$ as yellow solid. Yield $83 \%,{ }^{1} \mathrm{H}-\mathrm{NMR}(400 \mathrm{MHz}$, DMSO- $\left.d_{6}\right) \delta: 12.59(\mathrm{~s}, 1 \mathrm{H}), 8.22-8.20(\mathrm{dd}, J=8.0,1.6 \mathrm{~Hz}, 1 \mathrm{H})$, 7.97-7.92 (ddd, $J=8.7,7.2,1.7 \mathrm{~Hz}, 1 \mathrm{H}), 7.69(\mathrm{~d}, J=8.1 \mathrm{~Hz}$, $1 \mathrm{H}), 7.56-7.52(\mathrm{t}, J=7.5 \mathrm{~Hz}, 1 \mathrm{H}), 7.47-7.38(\mathrm{~m}, 3 \mathrm{H}), 7.36$ (d, $J=2.1 \mathrm{~Hz}, 1 \mathrm{H}), 7.18(\mathrm{~d}, J=1.5 \mathrm{~Hz}, 1 \mathrm{H}), 7.06-7.03$ (ddd, $J=7.7,2.4,1.5 \mathrm{~Hz}, 1 \mathrm{H}), 3.87(\mathrm{~s}, 3 \mathrm{H}) .{ }^{13} \mathrm{C}-\mathrm{NMR}(101 \mathrm{MHz}$, DMSO- $\left.d_{6}\right) \delta: 181.81,161.63,160.28,156.57,156.30,149.43$, $140.08,136.97,130.67,125.94,125.17,120.54,120.04,118.51$, 115.72, 112.91, 108.97, 107.92, 105.95, 55.75. ESI-HR-MS Calcd for $\mathrm{C}_{20} \mathrm{H}_{14} \mathrm{O}_{4}[\mathrm{M}+\mathrm{H}]^{+}:$319.0926. Found: 319.0965 .

1-Hydroxy-3-(4-methoxyphenyl)-9H-xanthen-9-one (4j)

Compound 2 was treated with (4-methoxyphenyl)boronic acid (3j) according to general procedure to give the desired product $\mathbf{4} \mathbf{j}$ as yellow solid. Yield $90 \%,{ }^{1} \mathrm{H}-\mathrm{NMR}(400 \mathrm{MHz}$, DMSO- $\left.d_{6}\right) \delta: 12.59(\mathrm{~s}, 1 \mathrm{H}), 8.21-8.19(\mathrm{dd}, J=8.0,1.6 \mathrm{~Hz}$, $1 \mathrm{H}), 7.95-7.91$ (ddd, $J=8.7,7.2,1.7 \mathrm{~Hz}, 1 \mathrm{H}), 7.85-7.82(\mathrm{~d}$, $J=8.9 \mathrm{~Hz}, 2 \mathrm{H}), 7.68(\mathrm{~d}, J=8.0 \mathrm{~Hz}, 1 \mathrm{H}), 7.56-7.49(\mathrm{td}, J=7.5$, $1.0 \mathrm{~Hz}, 1 \mathrm{H}), 7.38$ (d, $J=1.6 \mathrm{~Hz}, 1 \mathrm{H}), 7.13(\mathrm{~d}, J=1.6 \mathrm{~Hz}, 1 \mathrm{H})$, $7.11-7.04$ (d, $J=8.9 \mathrm{~Hz}, 2 \mathrm{H}), 3.83$ (s, 3H). ${ }^{13} \mathrm{C}-\mathrm{NMR}(101 \mathrm{MHz}$, DMSO- $\left.d_{6}\right) \delta$ : 181.61, 161.69, 160.84, 156.69, 156.27, 149.16, $136.86,130.62,129.14,125.90,125.12,120.55,118.48,115.01$, 108.05, 107.35, 104.92, 55.80. ESI-HR-MS Calcd for $\mathrm{C}_{20} \mathrm{H}_{14} \mathrm{O}_{4}$ $[\mathrm{M}+\mathrm{H}]^{+}:$319.0926. Found: 319.0960 .

3-(2,4-Dimethoxyphenyl)-1-hydroxy-9H-xanthen-9-one (4k)

Compound $\mathbf{2}$ was treated with (2,4-dimethoxyphenyl)boronic acid (3k) according to general procedure to give the desired product $\mathbf{4 k}$ as yellow solid. Yield $91 \%,{ }^{1} \mathrm{H}-\mathrm{NMR}$ $\left(400 \mathrm{MHz}, \mathrm{CDCl}_{3}\right) \delta: 12.58(\mathrm{~s}, 1 \mathrm{H}), 8.30-8.28$ (dd, $J=8.0$, $1.6 \mathrm{~Hz}, 1 \mathrm{H}), 7.77-7.73$ (ddd, $J=8.7,7.1,1.7 \mathrm{~Hz}, 1 \mathrm{H}), 7.49-7.47$ (dd, $J=8.5,1.0 \mathrm{~Hz}, 1 \mathrm{H}), 7.41-7.37(\mathrm{ddd}, J=8.1,7.1,1.1 \mathrm{~Hz}$, $1 \mathrm{H}), 7.35-7.33(\mathrm{~d}, J=8.2 \mathrm{~Hz}, 1 \mathrm{H}), 7.15-7.14(\mathrm{~d}, J=1.5 \mathrm{~Hz}$, $1 \mathrm{H}), 7.00-6.99(\mathrm{~d}, J=1.5 \mathrm{~Hz}, 1 \mathrm{H}), 6.64-6.56(\mathrm{~m}, 2 \mathrm{H}), 3.88$ $(\mathrm{s}, 3 \mathrm{H}), 3.86(\mathrm{~s}, 3 \mathrm{H}) .{ }^{13} \mathrm{C}-\mathrm{NMR}\left(126 \mathrm{MHz}, \mathrm{CDCl}_{3}\right) \delta: 181.85$, $161.42,161.15,157.72,156.35,155.86,147.70,135.35,131.42$, $125.97,123.93,121.72,120.77,117.86,111.55,108.00,107.46$, 104.94, 99.08, 55.64, 55.50. ESI-HR-MS Calcd for $\mathrm{C}_{21} \mathrm{H}_{16} \mathrm{O}_{5}$ $[\mathrm{M}+\mathrm{H}]^{+}:$349.1031. Found: 349.1071 .

3-(3,4-Dimethoxyphenyl)-1-hydroxy-9H-xanthen-9-one (4I)

Compound 2 was treated with (3,4-dimethoxyphenyl)boronic acid (3k) according to general procedure to give the desired product $4 \mathbf{l}$ as yellow solid. Yield $86 \%,{ }^{1} \mathrm{H}-\mathrm{NMR}$ $\left(400 \mathrm{MHz}, \mathrm{CDCl}_{3}\right) \delta: 12.60(\mathrm{~s}, 1 \mathrm{H}), 8.23-8.21$ (dd, $J=8.0$, $1.6 \mathrm{~Hz}, 1 \mathrm{H}), 7.69$ (ddd, $J=8.6,7.3,1.6 \mathrm{~Hz}, 1 \mathrm{H}), 7.42(\mathrm{~d}$, $J=8.4 \mathrm{~Hz}, \quad 1 \mathrm{H}), \quad 7.36-7.32 \quad(\mathrm{t}, \quad J=7.3 \mathrm{~Hz}, 1 \mathrm{H}), \quad 7.21-7.18$ (dd, $J=7.3,2.1 \mathrm{~Hz}, 1 \mathrm{H}), 7.12(\mathrm{~d}, J=2.1 \mathrm{~Hz}, 1 \mathrm{H}), 7.08$ (d, $J=1.4 \mathrm{~Hz}, 1 \mathrm{H}), 6.96(\mathrm{~d}, J=1.5 \mathrm{~Hz}, 1 \mathrm{H}), 6.91(\mathrm{~d}, J=8.4 \mathrm{~Hz}$, $1 \mathrm{H}), 3.91(\mathrm{~s}, 3 \mathrm{H}), 3.88$ (s, 3H). ${ }^{13} \mathrm{C}-\mathrm{NMR}\left(101 \mathrm{MHz}, \mathrm{CDCl}_{3}\right) \delta$ : $180.77,160.90,155.50,155.30,148.97,148.66,148.27,134.46$,
$130.98,124.98,123.09,119.75,118.98,116.79,110.37,109.20$, 107.61, 106.56, 103.98, 54.99, 28.68. ESI-HR-MS Calcd for $\mathrm{C}_{21} \mathrm{H}_{16} \mathrm{O}_{5}[\mathrm{M}+\mathrm{H}]^{+}:$349.1031. Found: 349.1071 .

3-(3,5-Dimethoxyphenyl)-1-hydroxy-9H-xanthen-9-one (4m)

Compound $\mathbf{2}$ was treated with (3,5-dimethoxyphenyl)boronic acid (3m) according to general procedure to give the desired product $\mathbf{4 m}$ as yellow solid. Yield $82 \%,{ }^{1} \mathrm{H}-\mathrm{NMR}$ $\left(400 \mathrm{MHz}, \mathrm{CDCl}_{3}\right) \delta: 12.66(\mathrm{~s}, 1 \mathrm{H}), 8.31-8.29$ (dd, $J=8.0$, $1.6 \mathrm{~Hz}, 1 \mathrm{H}), 7.79-7.75$ (ddd, $J=8.7,7.1,1.7 \mathrm{~Hz}, 1 \mathrm{H}), 7.51-7.49$ (dd, $J=8.6,1.0 \mathrm{~Hz}, 1 \mathrm{H}), 7.44-7.40(\mathrm{ddd}, J=8.1,7.2,1.1 \mathrm{~Hz}$, $1 \mathrm{H}), 7.17(\mathrm{~d}, J=1.6 \mathrm{~Hz}, 1 \mathrm{H}), 7.04(\mathrm{~d}, J=1.6 \mathrm{~Hz}, 1 \mathrm{H}), 6.80$ (d, $J=2.3 \mathrm{~Hz}, 2 \mathrm{H}), 6.54(\mathrm{t}, J=2.2 \mathrm{~Hz}, 1 \mathrm{H}), 3.87(\mathrm{~s}, 6 \mathrm{H})$. ${ }^{13} \mathrm{C}-\mathrm{NMR}\left(126 \mathrm{MHz}, \mathrm{CDCl}_{3}\right) \delta: 181.93,161.90,161.19,156.41$, $149.90,141.50,135.57,126.02,124.16,120.75,117.89$, 109.26, 108.05, 105.71, 105.55, 100.95, 99.48, 55.52. ESI-HR-MS Calcd for $\mathrm{C}_{21} \mathrm{H}_{16} \mathrm{O}_{5}[\mathrm{M}+\mathrm{H}]^{+}$: 349.1031. Found: 349.1071.

1-Hydroxy-3-(3,4,5-trimethoxyphenyl)-9H-xanthen-9-one (4n)

Compound 2 was treated with (3,4,5-trimethoxyphenyl)boronic acid (3n) according to general procedure to give the desired product $4 \mathbf{n}$ as yellow solid. Yield $82 \%,{ }^{1} \mathrm{H}-\mathrm{NMR}$ $\left(400 \mathrm{MHz}, \mathrm{CDCl}_{3}\right) \delta: 12.61(\mathrm{~s}, 1 \mathrm{H}), 8.23-8.21$ (dd, $J=8.0$, $1.6 \mathrm{~Hz}, 1 \mathrm{H}), 7.72-7.68(\mathrm{ddd}, J=8.7,7.2,1.7 \mathrm{~Hz}, 1 \mathrm{H}), 7.42(\mathrm{~d}$, $J=7.9 \mathrm{~Hz}, 1 \mathrm{H}), 7.36-7.32(\mathrm{td}, J=7.6,1.0 \mathrm{~Hz}, 1 \mathrm{H}), 7.07(\mathrm{~d}$, $J=1.6 \mathrm{~Hz}, 1 \mathrm{H}), 6.95(\mathrm{~d}, J=1.6 \mathrm{~Hz}, 1 \mathrm{H}), 6.80(\mathrm{~s}, 2 \mathrm{H}), 3.89$ $(\mathrm{s}, 6 \mathrm{H}), 3.85(\mathrm{~s}, 3 \mathrm{H}) .{ }^{13} \mathrm{C}-\mathrm{NMR}\left(101 \mathrm{MHz}, \mathrm{CDCl}_{3}\right) \delta: 180.83$, $160.88,155.42,155.29,152.57,148.88,137.90,134.56,134.03$, $125.00,123.17,119.72,116.80,107.98,106.81,104.38,103.51$, 59.98, 55.24. ESI-HR-MS Calcd for $\mathrm{C}_{22} \mathrm{H}_{18} \mathrm{O}_{6}[\mathrm{M}+\mathrm{H}]^{+}$: 379.1137. Found: 379.1175.

General Procedure for the Preparation of (4o-4q) To a solution of methoxycarbonyl compound (4d-4f) $(0.346 \mathrm{~g}$, $1.0 \mathrm{mmol})$ in $\mathrm{MeOH}(30 \mathrm{~mL})$ was added $2 \mathrm{M}$ aqueous $\mathrm{NaOH}$ solution $(6 \mathrm{~mL})$ and the mixture was heated at $70^{\circ} \mathrm{C}$ for $6 \mathrm{~h}$. After completion monitored by TLC, the reaction was cooled to ambient temperature, $10 \%$ aqueous solution of $\mathrm{HCl}$ were sequentially added until acidic $\mathrm{pH}$. The mixture was extracted with EtOAc, the combined organic layers were dried over $\mathrm{Na}_{2} \mathrm{SO}_{4}$ and the solvent was evaporated in vacuum. The residue was purified by flash chromatography on silica gel gave the corresponding carboxyl compounds $\mathbf{4 o - 4 q}$

2-(1-Hydroxy-9-oxo-9H-xanthen-3-yl)benzoic Acid (4o)

Hydrolysis of compound $\mathbf{4 d}$ according to general procedure gave the desired product $\mathbf{4 0}$ as yellow solid. Yield 92\%, ${ }^{1} \mathrm{H}-\mathrm{NMR}$ (400 MHz, DMSO- $d_{6}$ ) $\delta: 12.97$ (br, 1H), 12.53 (s, 1H), 8.17-8.15 (dd, $J=7.9,1.7 \mathrm{~Hz}, 1 \mathrm{H}), 7.91-7.86$ (ddd, $J=8.7,7.2,1.7 \mathrm{~Hz}, 1 \mathrm{H}), 7.79-7.77(\mathrm{dd}, J=7.7,1.4 \mathrm{~Hz}, 1 \mathrm{H})$, $7.65-7.58(\mathrm{~m}, 2 \mathrm{H}), 7.54-7.43(\mathrm{~m}, 3 \mathrm{H}), 6.99(\mathrm{~d}, J=1.5 \mathrm{~Hz}, 1 \mathrm{H})$, $6.73(\mathrm{~d}, J=1.5 \mathrm{~Hz}, 1 \mathrm{H}) .{ }^{13} \mathrm{C}-\mathrm{NMR}\left(101 \mathrm{MHz}, \mathrm{DMSO}-d_{6}\right) \delta$ : $181.85,169.36,161.03,156.23,155.75,150.98,140.30,136.47$, $132.27,131.47,130.43,130.00,128.68,125.91,124.77,120.52$, 118.27, 110.98, 107.69, 107.58. EI-HR-MS Calcd for $\mathrm{C}_{21} \mathrm{H}_{14} \mathrm{O}_{5}$ $[\mathrm{M}+\mathrm{H}]^{+}$: 333.0718. Found: 333.0748.

3-(1-Hydroxy-9-oxo-9H-xanthen-3-yl)benzoic Acid (4p)

Hydrolysis of compound $4 \mathbf{e}$ according to general procedure gave the desired product $\mathbf{4 p}$ as yellow solid. Yield $90 \%,{ }^{1} \mathrm{H}-\mathrm{NMR}$ (400 MHz, DMSO- $\left.d_{6}\right) \delta: 13.21$ (br, $\left.1 \mathrm{H}\right)$, $12.57(\mathrm{~s}, 1 \mathrm{H}), 8.25$ (t, $J=1.8 \mathrm{~Hz}, 1 \mathrm{H}), 8.19-8.17$ (dd, $J=8.0$, $1.7 \mathrm{~Hz}, 1 \mathrm{H}), 8.07-8.04(\mathrm{dt}, J=7.8,1.5 \mathrm{~Hz}, 1 \mathrm{H}), 8.02-7.99$ (dt, $J=7.8,1.3 \mathrm{~Hz}, 1 \mathrm{H}), 7.91$ (ddd, $J=8.7,7.2,1.5 \mathrm{~Hz}, 1 \mathrm{H})$, $7.67-7.61(\mathrm{~m}, 2 \mathrm{H}), 7.52-7.48(\mathrm{~m}, 1 \mathrm{H}), 7.41(\mathrm{~d}, J=1.6 \mathrm{~Hz}, 1 \mathrm{H})$, 
$7.14(\mathrm{~d}, J=1.6 \mathrm{~Hz}, 1 \mathrm{H}) .{ }^{13} \mathrm{C}-\mathrm{NMR}\left(101 \mathrm{MHz}, \mathrm{DMSO}-d_{6}\right) \delta$ : $181.89,167.54,161.83,156.71,156.33,148.56,139.04,137.09$, $132.24,130.47,130.12,129.21,128.44,126.00,125.29,120.59$, 118.60, 108.99, 108.12, 106.08. EI-HR-MS Calcd for $\mathrm{C}_{20} \mathrm{H}_{12} \mathrm{O}_{5}$ $[\mathrm{M}+\mathrm{H}]^{+}$: 333.0718. Found: 333.0750.

4-(1-Hydroxy-9-oxo-9H-xanthen-3-yl)benzoic Acid (4q)

Hydrolysis of compound $\mathbf{4 f}$ according to general procedure gave the desired product $\mathbf{4 q}$ as yellow solid. Yield $93 \%$, ${ }^{1} \mathrm{H}-\mathrm{NMR}\left(400 \mathrm{MHz}, \mathrm{DMSO}-d_{6}\right) \delta$ : 12.61 (s, $\left.1 \mathrm{H}\right), 8.23-8.21$ $(\mathrm{dd}, J=8.0,1.7 \mathrm{~Hz}, 1 \mathrm{H}), 8.07-8.05(\mathrm{~d}, J=8.5 \mathrm{~Hz}, 2 \mathrm{H})$, 7.99-7.97 (d, $J=8.5 \mathrm{~Hz}, 2 \mathrm{H}), 7.96-7.93(\mathrm{~m}, 1 \mathrm{H}), 7.71-7.69$ (dd, $J=8.5,0.9 \mathrm{~Hz}, 1 \mathrm{H}), 7.56-7.52(\mathrm{ddd}, J=8.1,7.1,1.0 \mathrm{~Hz}, 1 \mathrm{H})$, $7.49(\mathrm{~d}, J=1.6 \mathrm{~Hz}, 1 \mathrm{H}), 7.22(\mathrm{~d}, J=1.6 \mathrm{~Hz}, 1 \mathrm{H}) .{ }^{13} \mathrm{C}-\mathrm{NMR}$ $\left(126 \mathrm{MHz}, \mathrm{DMSO}-d_{6}\right) \delta: 181.85,167.36,161.73,156.61,156.29$, $148.13,142.55,137.05,131.64,130.44,128.05,125.95,125.24$, 120.55, 118.54, 109.08, 108.27, 106.20. ESI-HR-MS Calcd for $\mathrm{C}_{20} \mathrm{H}_{12} \mathrm{O}_{5}[\mathrm{M}+\mathrm{H}]^{+}$: 333.0718. Found: 333.0759.

General Procedure for the Preparation of $(4 \mathbf{r}-\mathbf{4 x})$ To a solution of methoxyl xanthones $\mathbf{4 h}-\mathbf{4 n}(1.0 \mathrm{mmol})$ in $20 \mathrm{~mL}$ dried dichloromethane was added boron tribromide (2.0 equiv per hydroxyl group) dropwise at $0^{\circ} \mathrm{C}$. The mixture was stirred at $0^{\circ} \mathrm{C}$ for $30 \mathrm{~min}$ and then stirring reacted overnight at room temperature. When the reaction completed, the mixture was quenched with ice water and extracted by $\mathrm{CH}_{2} \mathrm{Cl}_{2}$ twice. The combined extract was then washed with brine and dried over $\mathrm{Na}_{2} \mathrm{SO}_{4}$. The solvent was removed under reduced pressure and the crude product was purified by flash chromatography on silica gel gave the corresponding desired C3-polyphenol substituted compounds $\mathbf{4 r}-\mathbf{4 x}$.

1-Hydroxy-3-(2-hydroxyphenyl)-9H-xanthen-9-one (4r)

Demethylation of compound $\mathbf{4 h}$ according to general procedure gave the desired product $4 \mathbf{r}$ as yellow solid. Yield 91\%, ${ }^{1} \mathrm{H}-\mathrm{NMR}\left(400 \mathrm{MHz}, \mathrm{CDCl}_{3}\right) \delta: 12.72(\mathrm{~s}, 1 \mathrm{H}), 8.31(\mathrm{~d}$, $J=8.0 \mathrm{~Hz}, 1 \mathrm{H}), 7.82-7.78(\mathrm{td}, J=7.8,1.5 \mathrm{~Hz}, 1 \mathrm{H}), 7.51(\mathrm{~d}$, $J=8.5 \mathrm{~Hz}, 1 \mathrm{H}), 7.44(\mathrm{t}, J=7.6 \mathrm{~Hz}, 1 \mathrm{H}), 7.35(\mathrm{t}, J=7.5 \mathrm{~Hz}$, 2H), $7.13(\mathrm{~d}, J=1.2 \mathrm{~Hz}, 1 \mathrm{H}), 7.08$ (d, $J=7.6 \mathrm{~Hz}, 1 \mathrm{H}), 7.03$ $(\mathrm{d}, J=8.3 \mathrm{~Hz}, 1 \mathrm{H}), 6.98(\mathrm{~d}, J=1.2 \mathrm{~Hz}, 1 \mathrm{H}), 5.49(\mathrm{~s}, 1 \mathrm{H})$. ${ }^{13} \mathrm{C}-\mathrm{NMR}$ (101 MHz, DMSO- $d_{6}$ ) $\delta$ : 181.67, 160.73, 156.23, $155.80,155.20,148.30,136.80,130.84,130.62,126.02,125.86$, 125.01, 120.47, 120.13, 118.50, 116.91, 111.28, 108.13, 107.30 . ESI-HR-MS Calcd for $\mathrm{C}_{19} \mathrm{H}_{12} \mathrm{O}_{4}\left[\mathrm{M}+\mathrm{H}^{+}\right.$: 305.0769 . Found: 305.0804 .

1-Hydroxy-3-(3-hydroxyphenyl)-9H-xanthen-9-one (4s)

Demethylation of compound $4 \mathbf{i}$ according to general procedure gave the desired product $4 \mathrm{~s}$ as yellow solid. Yield $88 \%$, ${ }^{1} \mathrm{H}-\mathrm{NMR}\left(400 \mathrm{MHz}, \mathrm{DMSO}-d_{6}\right) \delta: 12.59$ (s, $\left.1 \mathrm{H}\right), 9.69$ (s, $\left.1 \mathrm{H}\right)$, $8.22-8.20(\mathrm{~d}, J=7.9 \mathrm{~Hz}, 1 \mathrm{H}), 7.96-7.92(\mathrm{t}, J=7.8 \mathrm{~Hz}, 1 \mathrm{H})$, $7.71-7.68(\mathrm{~d}, J=8.5 \mathrm{~Hz}, 1 \mathrm{H}), 7.55-7.52(\mathrm{t}, J=7.5 \mathrm{~Hz}, 1 \mathrm{H})$, $7.35-7.29(\mathrm{~m}, 2 \mathrm{H}), 7.25-7.23(\mathrm{~d}, J=7.7 \mathrm{~Hz}, 1 \mathrm{H}), 7.15-7.14(\mathrm{t}$, $J=2.1 \mathrm{~Hz}, 1 \mathrm{H}), 7.06(\mathrm{~s}, 1 \mathrm{H}), 6.90-6.88(\mathrm{dd}, J=8.0,2.3 \mathrm{~Hz}$, $1 \mathrm{H}) .{ }^{13} \mathrm{C}-\mathrm{NMR}\left(126 \mathrm{MHz}, \mathrm{DMSO}-d_{6}\right) \delta: 181.77,161.61,158.40$, $156.56,156.28,149.72,140.03,136.93,130.68,129.16,125.92$, 125.16, 120.54, 118.50, 116.39, 114.39, 108.73, 105.68, 104.56 . ESI-HR-MS Calcd for $\mathrm{C}_{19} \mathrm{H}_{12} \mathrm{O}_{4}\left[\mathrm{M}+\mathrm{H}^{+}\right.$: 305.0769. Found: 305.0808 .

1-Hydroxy-3-(4-hydroxyphenyl)-9H-xanthen-9-one (4t)

Demethylation of compound $\mathbf{4} \mathbf{j}$ according to general procedure gave the desired product $\mathbf{4 t}$ as yellow solid. Yield $93 \%,{ }^{1} \mathrm{H}-\mathrm{NMR} \quad\left(400 \mathrm{MHz}, \mathrm{DMSO}-d_{6}\right) \quad \delta: 12.57 \quad(\mathrm{~s}, 1 \mathrm{H})$, $9.89(\mathrm{~s}, 1 \mathrm{H}), 8.20-8.18(\mathrm{dd}, J=7.9,1.7 \mathrm{~Hz}, 1 \mathrm{H}), 7.94-7.90$ (ddd, $J=8.7,7.1,1.7 \mathrm{~Hz}, 1 \mathrm{H}), 7.72-7.70(\mathrm{~d}, J=8.7 \mathrm{~Hz}, 2 \mathrm{H})$, $7.67-7.65(\mathrm{~d}, J=8.2 \mathrm{~Hz}, 1 \mathrm{H}), 7.54-7.50(\mathrm{t}, J=7.5 \mathrm{~Hz}, 1 \mathrm{H})$, $7.32(\mathrm{~d}, J=1.6 \mathrm{~Hz}, 1 \mathrm{H}), 7.08(\mathrm{~d}, J=1.6 \mathrm{~Hz}, 1 \mathrm{H}), 6.91-6.88(\mathrm{~d}$, $J=8.7 \mathrm{~Hz}, 2 \mathrm{H}) .{ }^{13} \mathrm{C}-\mathrm{NMR}\left(126 \mathrm{MHz}, \mathrm{DMSO}-d_{6}\right) \delta: 181.51$, $161.65,159.35,156.66,156.23,149.58,136.77,129.16,128.98$, $125.86,125.06,120.54,118.45,116.38,107.75,107.12,104.55$. ESI-HR-MS Calcd for $\mathrm{C}_{19} \mathrm{H}_{12} \mathrm{O}_{4}[\mathrm{M}+\mathrm{H}]^{+}$: 305.0769. Found: 305.0810. Purity 97.2\%.

3-(2,4-Dihydroxyphenyl)-1-hydroxy-9H-xanthen-9-one (4u)

Demethylation of compound $\mathbf{4 k}$ according to general procedure gave the desired product $\mathbf{4} \mathbf{u}$ as yellow solid. Yield $90 \%,{ }^{1} \mathrm{H}-\mathrm{NMR}\left(400 \mathrm{MHz}\right.$, Acetone- $\left.d_{6}\right) \delta: 12.58(\mathrm{~s}, 1 \mathrm{H}), 8.74$ $(\mathrm{s}, 1 \mathrm{H}), 8.60(\mathrm{~s}, 1 \mathrm{H}), 8.28-8.25(\mathrm{dd}, J=7.9,1.7 \mathrm{~Hz}, 1 \mathrm{H})$, $7.93-7.89$ (ddd, $J=8.7,7.1,1.7 \mathrm{~Hz}, 1 \mathrm{H}), 7.63-7.61$ (dd, $J=8.6$, $1.0 \mathrm{~Hz}, 1 \mathrm{H}), 7.53-7.49$ (ddd, $J=8.1,7.1,1.0 \mathrm{~Hz}, 1 \mathrm{H}), 7.37-7.35$ $(\mathrm{d}, J=8.4 \mathrm{~Hz}, 1 \mathrm{H}), 7.31-7.30(\mathrm{~d}, J=1.5 \mathrm{~Hz}, 1 \mathrm{H}), 7.08-7.07$ $(\mathrm{d}, J=1.4 \mathrm{~Hz}, 1 \mathrm{H}), 6.59-6.58(\mathrm{~d}, J=2.3 \mathrm{~Hz}, 1 \mathrm{H}), 6.54-6.51$ $(\mathrm{dd}, J=8.4,2.4 \mathrm{~Hz}, 1 \mathrm{H}) .{ }^{13} \mathrm{C}-\mathrm{NMR}\left(126 \mathrm{MHz}\right.$, Acetone- $\left.d_{6}\right) \delta$ : $181.55,161.21,159.40,156.34,155.92,148.58,135.84,131.46$, $125.53,124.20,120.56,118.06,117.92,110.64,107.92,107.26$, 106.70, 103.35. ESI-HR-MS Calcd for $\mathrm{C}_{19} \mathrm{H}_{12} \mathrm{O}_{5}[\mathrm{M}+\mathrm{H}]^{+}$: 321.0718. Found: 321.0752.

3-(3,4-Dihydroxyphenyl)-1-hydroxy-9H-xanthen-9-one (4v)

Demethylation of compound $\mathbf{4 l}$ according to general procedure gave the desired product $\mathbf{4} \mathbf{v}$ as yellow solid. Yield $86 \%$, ${ }^{1} \mathrm{H}-\mathrm{NMR}\left(400 \mathrm{MHz}, \mathrm{DMSO}-d_{6}\right) \delta: 12.57$ (s, 1H), 9.47 (s, 1H), 9.19 (s, 1H), 8.21-8.18 (dd, $J=8.0,1.6 \mathrm{~Hz}, 1 \mathrm{H}), 7.95-7.90$ (ddd, $J=8.7,7.2,1.7 \mathrm{~Hz}, 1 \mathrm{H}), 7.68(\mathrm{~d}, J=8.0 \mathrm{~Hz}, 1 \mathrm{H}), 7.56-7.49$ (td, $J=7.5,1.0 \mathrm{~Hz}, 1 \mathrm{H}), 7.24(\mathrm{~d}, J=1.6 \mathrm{~Hz}, 1 \mathrm{H}), 7.21-7.14(\mathrm{~m}, 2 \mathrm{H})$, $6.99(\mathrm{~d}, J=1.5 \mathrm{~Hz}, 1 \mathrm{H}), 6.87(\mathrm{~d}, J=8.1 \mathrm{~Hz}, 1 \mathrm{H}) .{ }^{13} \mathrm{C}-\mathrm{NMR}$ $\left(101 \mathrm{MHz}, \mathrm{DMSO}-d_{6}\right) \delta: 181.49,161.58,156.61,156.24,149.90$, $147.62,146.24,136.75,129.62,125.86,125.05,120.54,119.25$, 118.47, 116.58, 114.81, 107.76, 107.13, 104.57. ESI-HR-MS Calcd for $\mathrm{C}_{19} \mathrm{H}_{12} \mathrm{O}_{5}[\mathrm{M}+\mathrm{H}]^{+}$: 321.0718. Found: 321.0751.

3-(3,5-Dihydroxyphenyl)-1-hydroxy-9H-xanthen-9-one (4w)

Demethylation of compound $\mathbf{4 m}$ according to general procedure gave the desired product $\mathbf{4 w}$ as yellow solid. Yield 91\%, ${ }^{1} \mathrm{H}-\mathrm{NMR}\left(400 \mathrm{MHz}\right.$, Acetone- $d_{6}$ ) $\delta$ : 12.68 (s, 1H), 8.52 (s, 2H), 8.29-8.27 (dd, $J=8.0,1.6 \mathrm{~Hz}, 1 \mathrm{H}), 7.96-7.92$ (ddd, $J=8.7,7.2,1.7 \mathrm{~Hz}, 1 \mathrm{H}), 7.65(\mathrm{~d}, J=8.4 \mathrm{~Hz}, 1 \mathrm{H}), 7.55-7.52(\mathrm{t}$, $J=7.1 \mathrm{~Hz}, 1 \mathrm{H}), 7.22(\mathrm{~d}, J=1.5 \mathrm{~Hz}, 1 \mathrm{H}), 7.00(\mathrm{~d}, J=1.5 \mathrm{~Hz}$, $1 \mathrm{H}), 6.76(\mathrm{~d}, J=2.2 \mathrm{~Hz}, 2 \mathrm{H}), 6.51-6.49(\mathrm{t}, J=2.1 \mathrm{~Hz}, 1 \mathrm{H})$. ${ }^{13} \mathrm{C}-\mathrm{NMR}\left(126 \mathrm{MHz}\right.$, Acetone- $\left.d_{6}\right) \delta$ : 181.79, 161.97, 159.16, $156.50,156.37,150.23,141.22,136.09,125.59,124.44,120.53$, 118.00, 108.51, 107.64, 105.88, 105.21, 103.37. ESI-HR-MS Calcd for $\mathrm{C}_{19} \mathrm{H}_{12} \mathrm{O}_{5}[\mathrm{M}+\mathrm{H}]^{+}:$321.0718. Found: 321.0759.

3-(3,4,5-Trihydroxyphenyl)-1-hydroxy-9H-xanthen-9-one $(4 x)$

Demethylation of compound $\mathbf{4 n}$ according to general procedure gave the desired product $\mathbf{4 x}$ as yellow solid. Yield $82 \%,{ }^{1} \mathrm{H}-\mathrm{NMR}\left(400 \mathrm{MHz}, \mathrm{DMSO}-d_{6}\right) \delta: 12.57$ (s, 1H), 9.18 (s, $2 \mathrm{H}), 8.65(\mathrm{~s}, 1 \mathrm{H}), 8.21-8.18(\mathrm{dd}, J=7.9,1.6 \mathrm{~Hz}, 1 \mathrm{H}), 7.93(\mathrm{td}$, $J=7.8,1.6 \mathrm{~Hz}, 1 \mathrm{H}), 7.68(\mathrm{~d}, J=8.3 \mathrm{~Hz}, 1 \mathrm{H}), 7.52$ (t, $J=7.5 \mathrm{~Hz}$, $1 \mathrm{H}), 7.14(\mathrm{~d}, J=1.4 \mathrm{~Hz}, 1 \mathrm{H}), 6.90(\mathrm{~d}, J=1.4 \mathrm{~Hz}, 1 \mathrm{H}), 6.73$ (s, 2H). ${ }^{13} \mathrm{C}-\mathrm{NMR}\left(101 \mathrm{MHz}, \mathrm{DMSO}-d_{6}\right) \delta: 181.49,161.52,156.56$, $156.25,150.25,146.99,136.76,135.54,128.79,125.86,125.06$, $120.55,118.51,107.77,107.18,106.63,104.58$. ESI-HR-MS Calcd for $\mathrm{C}_{19} \mathrm{H}_{12} \mathrm{O}_{6}[\mathrm{M}+\mathrm{H}]^{+}$: 337.0667. Found: 337.0703.

Assay of Tyrosinase Inhibitory Activities The inhibition of synthetic compounds on the diphenolase activitiy of mushroom tyrosinase was investigated according to reported procedure $^{12)}$ with some slight modifications. Briefly, all the 
synthesized compounds were screened for the diphenolase inhibitory activity of tyrosinase using L-DOPA as substrate. Synthetic compounds and kojic acid (used as a control) were dissolved in DMSO and their final concentration in DMSO was $5.0 \%$. Phosphate buffer, $\mathrm{pH} 6.8$, was used to dilute the DMSO stock solution of test compounds. In a 96-well plate, $10 \mu \mathrm{L}$ of mushroom tyrosinase $(30 \mathrm{U} / \mathrm{mL})$ was mixed with $10 \mu \mathrm{L}$ of samples in $170 \mu \mathrm{L}$ of Phosphate buffer solution $(50 \mathrm{mM})$ and the mixture was first pre-incubated for $10 \mathrm{~min}$ at $25^{\circ} \mathrm{C}$. After $10 \mu \mathrm{L}$ of L-DOPA $(0.85 \mathrm{mM})$ was added, the solution was monitored for the formation of dopachrome for $5 \mathrm{~min}$, by measuring the change in absorbance at $475 \mathrm{~nm}$. The measurement was completed in triplicate for each concentration and averaged before further calculation.

$\mathrm{IC}_{50}$ value was determined by interpolation of the doseresponse curves. The mode of inhibition of the enzyme was performed using the Lineweaver-Burk plot. The assay was performed varying the concentration of inhibitor and L-DOPA $(0.1,0.2,0.3$, and $0.4 \mu \mathrm{M})$. Kinetics constants were determined by the second plots of the apparent $K_{\mathrm{m}} / V_{\max }$ and/or $1 / V_{\max }$ versus the inhibitor concentration.

Molecular Modeling For the docking studies, Surflexdock in SYBYL X-2.1 was used. The Crystal structure of Agaricus bisporus tyrosinase (PDB code: 2 Y9X) was obtained from the Protein Data Bank. The structures of inhibitors were built in Sybyl package with standard bond lengths and angles and minimized using the Powell method. The termination of Gradient, force field of Tripos and charge of Gasteiger-Hückel were applied for the minimization process. For the protein, all the non-polar water molecules were removed from the crystal structure and hydrogens were added, as well as the AMBER FF99 force field were applied. The standard docking procedure was used with parameters set in default and three rounds of computation were carried out. After docking, residues within $5 \AA$ of the inhibitors were identified and the conformations that appeared the most frequently and possessed the lowest binding free energy were selected for further analysis.

Acknowledgments This research was funded by the Natural Science Foundation of Guangdong Province of China (grant number: Q17056013), Foundation of Educational Commission of Guangdong Province of China (Grant number: 2016KQNCX129), and Medical Scientific Research Foundation of Guangdong Province of China (A2017083, A2018421, B2018272).

Conflict of Interest The authors declare no conflict of interest.

Supplementary Materials The online version of this article contains supplementary materials.

\footnotetext{
References

1) Solomon E. I., Sundaram U. M., Machonkin T. E., Chem. Rev., 96, 2563-2606 (1996).

2) Lai X., Wichers H. J., Soler-Lopez M., Dijkstra B. W., Chem. Eur. J., 24, 47-55 (2018).

3) Goldfeder M., Kanteev M., Isaschar-Ovdat S., Adir N., Fishman A. Nat. Commun., 5, 4505-4510 (2014).

4) Ramsden C. A., Riley P. A., Bioorg. Med. Chem., 22, 2388-2395 (2014).
}

5) Decker H., Schweikardt T., Tuczek F., Angew. Chem. Int. Ed., 45, 4546-4550 (2016).

6) Chen Q. X., Liu X. D., Huang H., Biochemistry (Moscow), 68, 644-649 (2003).

7) Matsuura R., Ukeda H., Sawamura M., J. Agric. Food Chem., 54, 2309-2313 (2006).

8) Pinon A., Limami Y., Micallef L., Cook-Moreau J., Liagre B., Delage C., Duval R. E., Simon A., Exp. Cell Res., 317, 1669-1676 (2011).

9) Dong X., Zhu Q., Dai Y., He J., Pan H., Chen J., Zheng Z.-P., Food Chem., 192, 1033-1040 (2016).

10) Tan X., Song Y. H., Park C., Lee K.-W., Kim J. Y., Kim D. W., Kim K. D., Lee K. W., Curtis-Long M. J., Park K. H., Bioorg. Med. Chem., 24, 153-159 (2016).

11) Pillaiyar T., Manickam M., Namasivayam V., J. Enzyme Inhib. Med. Chem., 32, 403-425 (2017).

12) Buitrago E., Hardre R., Haudecoeur R., Jamet H., Belle C., Boumendjel A., Bubacco L., Reglier M., Curr. Top. Med. Chem., 16, 3033-3047 (2016).

13) Ullah S., Son S., Yun H. Y., Kim D. H., Chun P., Moon H. R., Expert Opin. Ther. Pat., 26, 347-362 (2016).

14) Yi W., Cao R., Chen Z., Yu L., Wen H., Yan Q., Ma L., Song H., Chem. Pharm. Bull., 58, 752-754 (2010).

15) Chen C.-Y., Lin L.-C., Yang W.-F., Bordon J., Wang H.-M. D., Curr. Org. Chem., 19, 4-18 (2015).

16) Lee S. Y., Baek N., Nam T., J. Enzyme Inhib. Med. Chem., 31, 1-13 (2016).

17) Zolghadri M., Bahrami A., Khan M. T. H., Munoz-Munoz J., Garcia-Molina F., Garcia-Canovas F., Saboury A. A., J. Enzyme Inhib. Med. Chem., 34, 279-309 (2019).

18) Tang J., Liu J., Wu F., Bioorg. Chem., 69, 29-36 (2016).

19) Pinto M. M. M., Sousa M. E., Nascimento M. S., Curr. Med. Chem., 12, 2517-2538 (2015).

20) Shagufta, Ahmad I., Eur. J. Med. Chem., 116, 267-280 (2016).

21) Ribeiro J., Veloso C., Fernandes C., Tiritan M. E., Pinto M. M. M., Molecules, 24, 180-213 (2019).

22) Jia Y., Xiong C., Nat. Prod. Res., 31, 704-706 (2017).

23) Panda S. S., Chand M., Sakhuja R., Jain S. C., Curr. Med. Chem., 20, 4481-4507 (2013).

24) Waszkielewicz A. M., Słoczyńska K., Pękala E., Żmudzki P., Siwek A., Gryboś A., Marona H., Chem. Biol. Drug Des., 89, 339-352 (2017).

25) Menéndez C. A., Biscussi B., Accordino S., Paula Murray A., Gerbino D. C., Appignanesi G. A., Bioorg. Chem., 75, 201-209 (2017).

26) Ke H., Morrisey J. M., Qu S., Chantarasriwong O., Mather M. W., Theodorakis E. A., Vaidya A. B., Antimicrob. Agents Chemother., 61, e01220-e16 (2016).

27) Mou L. Y., Wu H. Y., Ma E. G., Wang M. F., Duan Y. Q., Lei S., Li G. P., Nat. Prod. Res., 20, 1-7 (2018).

28) Chen X., Leng J., Rakesh K. P., Darshini N., Shubhavathi T., Vivek H. K., Mallesha N., Qin H. L., Med. Chem. Commun., 8, 1706-1719 (2017).

29) Wang P., Jiang L., Cao Y., Ye D., Zhou L., Molecules, 23, 13961429 (2018).

30) Liu Y., Ma L., Chen W.-H., Park H., Ke Z., Wang B., J. Phys. Chem. $B, 117,13464-13471$ (2013).

31) Santos C. M. M., Freitas M., Fernandes E., Eur. J. Med. Chem., 157, 1460-1479 (2018).

32) Minniti E., Byl J. A. W., Riccardi L., Sissi C., Rosini M., De Vivo M., Minarini A., Osheroff N., Bioorg. Med. Chem. Lett., 27, 46874693 (2017).

33) Xia Y., Sun J., Clin. Exp. Dermatol., 43, 149-157 (2018).

34) Ahmad I., Shagufta, Eur. J. Med. Chem., 102, 375-386 (2015).

35) Liu J., Wu F., Chen C., Bioorg. Med. Chem., 25, 5142-5146 (2015)

36) Guo N., Wang C., Shang C., You X., Zhang L., Liu W., Int. J. Biol. Macromol., 118 (Pt A), 57-68 (2018). 
37) Kostopoulou I., Detsi A., Curr. Enzym. Inhib., 14, 3-17 (2018).

38) Uesugi D., Hamada H., Shimoda K., Kubota N., Ozaki S. I., Nagatani N., Biosci. Biotechnol. Biochem., 81, 226-230 (2017).

39) Kwong H. C., Chidan Kumar C. S., Mah S. H., Chia T. S., Quah C. K., Loh Z. H., Chandraju S., Lim G. K., PLOS ONE, 12, e0170117 (2017).

40) Ruzza P., Serra P. A., Fabbri D., Dettori M. A., Rocchitta G., Delogu G., Eur. J. Med. Chem., 126, 1034-1038 (2017).

41) Ley J. P., Bertram H. J., Bioorg. Med. Chem., 9, 1879-1885 (2001).

42) Yi W., Dubois C., Yahiaoui S., Haudecoeur R., Belle C., Song H., Hardré R., Réglier M., Boumendjel A., Eur. J. Med. Chem., 46, 4330-4335 (2011).
43) You A., Zhou J., Song S., Zhu G., Song H., Yi W., Bioorg. Med. Chem., 23, 924-931 (2015).

44) Song S., You A., Chen Z., Zhu G., Wen H., Song H., Yi W., Eur. J. Med. Chem., 139, 815-825 (2017).

45) Masters K.-S., Bräse S., Chem. Rev., 112, 3717-3776 (2012).

46) Yuanita E., Pranowo H. D., Siswanta D., Swasono R. T., Mustofa Z., Zulkarnain A. K., Abdul K., Syahri J., Chem. Chem. Technol, 12, 290-295 (2018)

47) Ismaya W. T., Rozeboom H. J., Weijn A., Mes J. J., Fusetti F., Wichers H. J., Dijkstra B. W., Biochemistry, 50, 5477-5486 (2011).

48) Mutahir S., Asim Khan M., Khan I. U., Yar M., Ashraf M., Tariq S., Ye R., Zhou B., Eur. J. Med. Chem., 134, 406-414 (2017). 